\title{
Review Article \\ Epithelial Electrolyte Transport Physiology and the Gasotransmitter Hydrogen Sulfide
}

\author{
Ervice Pouokam $^{1}$ and Mike Althaus ${ }^{2}$ \\ ${ }^{1}$ Institute for Veterinary Physiology and Biochemistry, Justus-Liebig University, Frankfurter Strasse 100, 35392 Giessen, Germany \\ ${ }^{2}$ Institute for Animal Physiology, Justus-Liebig University, Heinrich-Buff-Ring 26, 35392 Giessen, Germany
}

Correspondence should be addressed to Ervice Pouokam; ervice.pouokam-kamgne@vetmed.uni-giessen.de and Mike Althaus; mike.althaus@bio.uni-giessen.de

Received 29 October 2015; Accepted 17 December 2015

Academic Editor: Yi C. Zhu

Copyright (c) 2016 E. Pouokam and M. Althaus. This is an open access article distributed under the Creative Commons Attribution License, which permits unrestricted use, distribution, and reproduction in any medium, provided the original work is properly cited.

Hydrogen sulfide $\left(\mathrm{H}_{2} \mathrm{~S}\right)$ is a well-known environmental chemical threat with an unpleasant smell of rotten eggs. Aside from the established toxic effects of high-dose $\mathrm{H}_{2} \mathrm{~S}$, research over the past decade revealed that cells endogenously produce small amounts of $\mathrm{H}_{2} \mathrm{~S}$ with physiological functions. $\mathrm{H}_{2} \mathrm{~S}$ has therefore been classified as a "gasotransmitter." A major challenge for cells and tissues is the maintenance of low physiological concentrations of $\mathrm{H}_{2} \mathrm{~S}$ in order to prevent potential toxicity. Epithelia of the respiratory and gastrointestinal tract are especially faced with this problem, since these barriers are predominantly exposed to exogenous $\mathrm{H}_{2} \mathrm{~S}$ from environmental sources or sulfur-metabolising microbiota. In this paper, we review the cellular mechanisms by which epithelial cells maintain physiological, endogenous $\mathrm{H}_{2} \mathrm{~S}$ concentrations. Furthermore, we suggest a concept by which epithelia use their electrolyte and liquid transport machinery as defence mechanisms in order to eliminate exogenous sources for potentially harmful $\mathrm{H}_{2} \mathrm{~S}$ concentrations.

\section{Introduction}

"All things are poisons, for there is nothing without poisonous qualities. It is only the dose which makes a thing poison." This famous quote from Paracelsus (1493-1541) is still important for research in physiology and especially for recent investigations on a toxic gas, hydrogen sulfide, and its potential role as a physiologically relevant signalling molecule.

Hydrogen sulfide $\left(\mathrm{H}_{2} \mathrm{~S}\right)$ is well known as an environmental chemical threat and even more for its unpleasant smell of rotten eggs. The odour threshold for $\mathrm{H}_{2} \mathrm{~S}$ is about $0.003-$ $0.02 \mathrm{ppm}$ and concentrations above $50 \mathrm{ppm}$ have toxic effects such as irritations of the eye and respiratory tract [1]. At $150-200 \mathrm{ppm}_{2} \mathrm{~S}$, the olfactory sense for this gas is lost and higher concentrations lead to the formation of pulmonary oedema, unconsciousness, and eventually death [1]. The toxic effects of $\mathrm{H}_{2} \mathrm{~S}$ are mainly based on the inhibition of the mitochondrial respiratory chain, especially cytochrome $\mathrm{c}$ oxidase $[2,3]$. However, consistent with the principle of Paracelsus, research of the past decade has revealed that cells endogenously produce small amounts of $\mathrm{H}_{2} \mathrm{~S}$ which are not simply a metabolic by-product and play an important role in cellular signalling processes [4]. Similar to nitric oxide (NO) or carbon monoxide (CO), $\mathrm{H}_{2} \mathrm{~S}$ has therefore been classified as a "gasotransmitter," a gaseous cellular signalling molecule $[4,5]$. Furthermore, a therapeutic potential for low-dose $\mathrm{H}_{2} \mathrm{~S}$ has been discovered [4] and $\mathrm{H}_{2} \mathrm{~S}$-releasing pharmacological compounds have been designed [6] and are currently evaluated as potential therapeutics in various models of disease [7].

A major challenge for cells and tissues is the maintenance of physiological (low) concentrations of $\mathrm{H}_{2} \mathrm{~S}$ in order to prevent potential toxicity. In this review article, we describe epithelial reactions to $\mathrm{H}_{2} \mathrm{~S}$. We focus on epithelia of the respiratory and intestinal tract since these tissues are predominantly exposed to a variety of exogenous and potentially dangerous sources for $\mathrm{H}_{2} \mathrm{~S}$, that is, inhaled $\mathrm{H}_{2} \mathrm{~S}$ in the lung and microbiota-generated $\mathrm{H}_{2} \mathrm{~S}$ in the gut. Furthermore, epithelial cells endogenously produce low concentrations of $\mathrm{H}_{2} \mathrm{~S}$ with potential implications for cellular signalling 
processes. In line with the principle of Paracelsus, epithelia therefore have to find a balance between potentially toxic exogenous and physiological, endogenous $\mathrm{H}_{2} \mathrm{~S}$ concentrations. In the following sections we will describe the chemistry as well as sources of $\mathrm{H}_{2} \mathrm{~S}$ to which epithelia are exposed, their reactions to exogenous and endogenous $\mathrm{H}_{2} \mathrm{~S}$, and potential physiological/pathophysiological implications with respect to epithelial function.

\section{Hydrogen Sulfide: Properties, Exogenous Sources, and Enzymatic Production}

2.1. Chemical Properties of Hydrogen Sulfide. $\mathrm{H}_{2} \mathrm{~S}$ is a colourless and flammable gas characterized by its rotten eggs or blocked sewer smell. At $20^{\circ} \mathrm{C}$, one gram of $\mathrm{H}_{2} \mathrm{~S}$ will dissolve in $242 \mathrm{~mL}$ water. Temperature and time influence the concentration of $\mathrm{H}_{2} \mathrm{~S}$; temperature elevation increases the solubility of this gas. Oxidation occurring over time in solution leads to precipitation of elemental sulfur, giving a cloudy aspect to the solution (for review see [4]). Experimental work with this molecule is complicated since $\mathrm{H}_{2} \mathrm{~S}$ evaporates easily from aqueous solutions with a half-life on the minute time-scale $[4,8,9]$. In solution, $\mathrm{H}_{2} \mathrm{~S}$ is a weak acid, dissociating into the hydrosulfide anion or thiolate form $\mathrm{HS}^{-}$and the sulfide anion $\mathrm{S}^{2-}$ building the following equilibrium:

$$
\mathrm{H}_{2} \mathrm{~S} \longleftrightarrow \mathrm{HS}^{-} \longleftrightarrow \mathrm{S}^{2-}
$$

with $\mathrm{pKa}$ and $\mathrm{pKa} 2$ values of 6.9 and $>12$, respectively.

Consequently, at $37^{\circ} \mathrm{C}$ and physiological $\mathrm{pH}$, there are almost equal amounts of $\mathrm{H}_{2} \mathrm{~S}$ and $\mathrm{HS}^{-}$(but no $\mathrm{S}^{2-}$ ) in cells and tissues and nearly a $20 \% \mathrm{H}_{2} \mathrm{~S} / 80 \% \mathrm{HS}^{-}$ratio in extracellular fluid or plasma [4]. $\mathrm{H}_{2} \mathrm{~S}$ is highly lipophilic with a dipole moment of 0.97 [10], allowing for a rapid cell membrane permeation [11] and hence potential interference with cell respiration. Diffusion of $\mathrm{H}_{2} \mathrm{~S}$ into the cells is hence a primary problem of respiratory and intestinal epithelia which are predominantly exposed to exogenous and potentially dangerous levels of $\mathrm{H}_{2} \mathrm{~S}$.

\subsection{Exogenous and Endogenous $\mathrm{H}_{2} \mathrm{~S}$ Sources}

2.2.1. Exogenous $\mathrm{H}_{2} \mathrm{~S}$ Sources. There are organic and inorganic sources of $\mathrm{H}_{2} \mathrm{~S}$ (Figure 1). The pulmonary epithelium can be exposed to $\mathrm{H}_{2} \mathrm{~S}$ by inhalation of environmental $\mathrm{H}_{2} \mathrm{~S}$ gas (Figure 1(a)). $\mathrm{H}_{2} \mathrm{~S}$ may be released by volcanoes as natural gas or contained in sulfur deposits or (healing) sulfur springs. Additional significant $\mathrm{H}_{2} \mathrm{~S}$ sources are industrial processes such as petroleum refinery, rayon manufacturing, and paper, swine, and pulp mill industry [4]. 125,000 employees in 73 industries of the United States are potentially exposed to $\mathrm{H}_{2} \mathrm{~S}$ [4].

In the intestinal tract, methionine- or cysteine-rich diet may end up as $\mathrm{H}_{2} \mathrm{~S}$ production/release. The intestinal flora may produce $\mathrm{H}_{2} \mathrm{~S}$ via sulfate-reducing bacteria (SRB) (Figure 1(b), Table 1). SRBs use several substrates like short-chain fatty acids, other organic acids, or alcohol as electron donors for reduction of sulfate or other oxidized sulfur molecules to produce $\mathrm{H}_{2} \mathrm{~S}$. Furthermore, endogenous substrates in the large intestine, such as sulfated polysaccharides (sulfomucins), can be used by the microflora for $\mathrm{H}_{2} \mathrm{~S}$ generation $[12,13]$. Sulfates may also be directly delivered by food such as dried fruits, nuts, bread, wine, or brassica vegetables. The key bacterial enzyme used during these processes is dissimilatory sulfite reductase [14]. Furthermore, Shatalin and colleagues demonstrated that clinically relevant and pathogenic nonsulfur bacteria such as Bacillus anthracis, Pseudomonas aeruginosa, Staphylococcus aureus, and Escherichia coli produce $\mathrm{H}_{2} \mathrm{~S}$ endogenously [15]. These species contain orthologues of the mammalian $\mathrm{H}_{2} \mathrm{~S}$-generating enzymes cystathionine- $\beta$-synthase (CBS), cystathionine- $\gamma$-lyase (CSE), and 3-mercaptopyruvate sulfurtransferase (3MST) and metabolize cysteine [15]. Overall, up to millimolar $\mathrm{H}_{2} \mathrm{~S}$ concentrations can occur in the content of human colon $[13,16]$ due to food compounds and activity of the intestinal flora.

In experimental studies, exogenous $\mathrm{H}_{2} \mathrm{~S}$ is mainly administered by " $\mathrm{H}_{2} \mathrm{~S}$ donors." Sulfur salts such as $\mathrm{NaHS}, \mathrm{Na}_{2} \mathrm{~S}$, and Lawesson's reagent are routinely used for $\mathrm{H}_{2} \mathrm{~S}$ delivery. However, these molecules are fast donors (in fact, these salts readily dissociate), contrasting with a continuous and more physiologically relevant production and release of $\mathrm{H}_{2} \mathrm{~S}$ which may occur in the body. Synthetic slow-releasing $\mathrm{H}_{2} \mathrm{~S}$ donors are, for example, GYY4137 or ATB-429 (for review, see $[6,17])$. Natural $\mathrm{H}_{2} \mathrm{~S}$ donors are, for example, compounds in garlic extracts such as diallyl poly(di,tri)sulfides which slowly release $\mathrm{H}_{2} \mathrm{~S}$. Also the sulfur-compounds Sallylcysteine (SAC) and allicin are found in garlic. These organic polysulfides may react with intracellular thiols like glutathione (GSH) to produce $\mathrm{H}_{2} \mathrm{~S}[4]$.

2.2.2. Endogenous, Intracellular $\mathrm{H}_{2} \mathrm{~S} . \mathrm{H}_{2} \mathrm{~S}$ is endogenously produced by various cell types, including epithelial cells, as a result of L-cysteine metabolism. For the detailed biochemistry of cellular $\mathrm{H}_{2} \mathrm{~S}$ production pathways, the reader is referred to excellent recent review articles [18, 19]. In the past years, a growing body of evidence suggests a concept by which intracellular $\mathrm{H}_{2} \mathrm{~S}$ concentrations are determined by (1) its enzymatic production; (2) its intracellular storage as bound sulfane sulfur; and (3) its oxidative degradation by mitochondria.

(1) Enzymatic $\mathrm{H}_{2} \mathrm{~S}$ Production. $\mathrm{H}_{2} \mathrm{~S}$ is generated by three enzymes: CBS, CSE and 3MST. L-cysteine is the substrate for pyridoxal- $5^{\prime}$-phosphate (vitamin B6) dependent CBS and CSE. However, it can be synthesized from Lmethionine through the transsulfuration pathway catalysed by methionine adenosyltransferase (MAT) and glycine $\mathrm{N}$ methyltransferase (GNMT). Serine is then transferred to homocysteine leading to cystathionine, a reaction catalysed by CBS. CSE converts cystathionine to cysteine. Cysteine may be converted to L-cystine which in turn will be converted to thiocysteine and further to $\mathrm{H}_{2} \mathrm{~S}$. CSE and CBS together catalyse the production of $\mathrm{H}_{2} \mathrm{~S}$ from cysteine. The abovementioned processes occur within the cytosol. Cysteine aminotransferase (CAT) and 3-mercaptopyruvate sulfur transferase (MPST), both found in cytosol and mitochondria, catalyse 

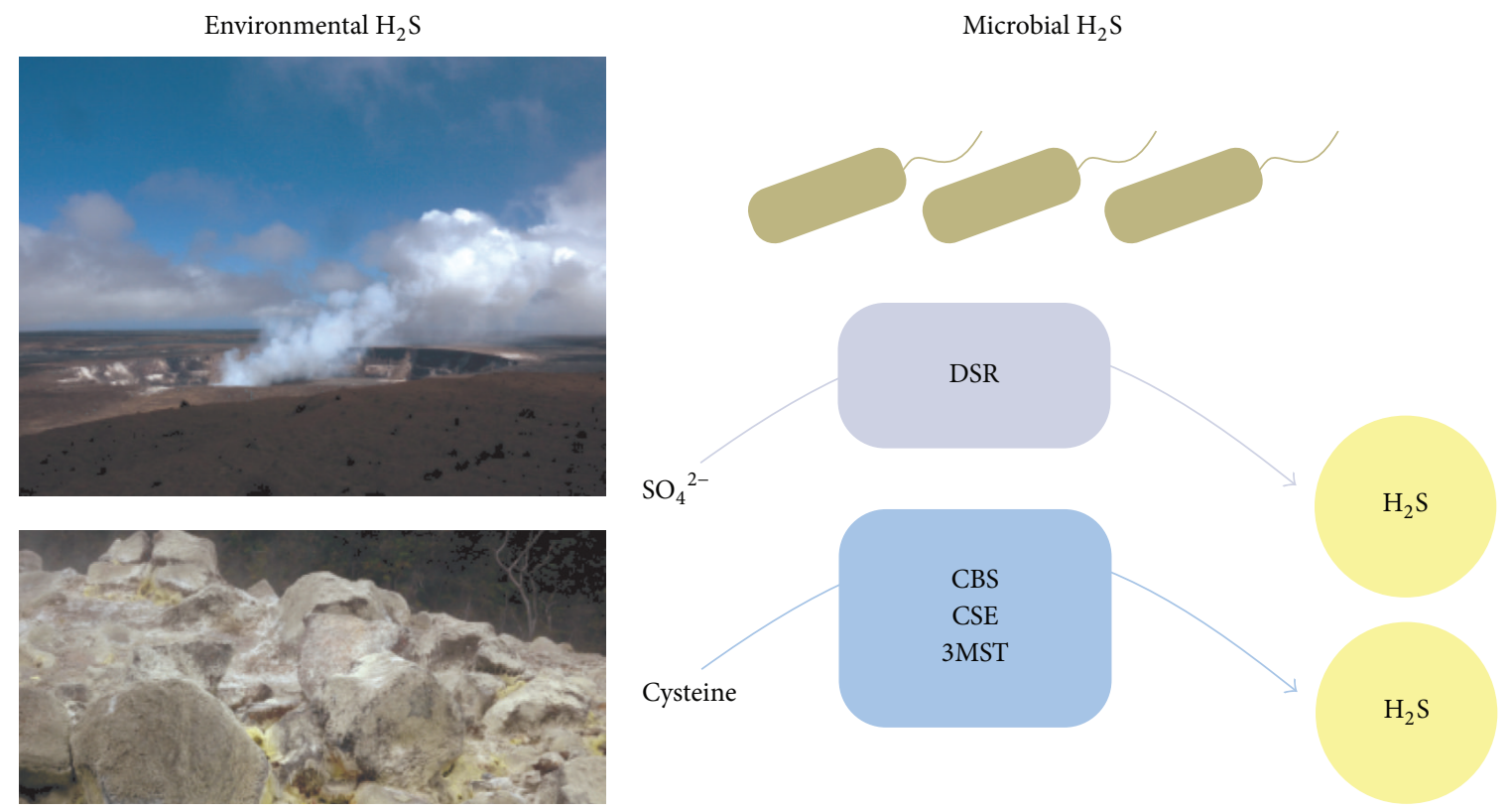

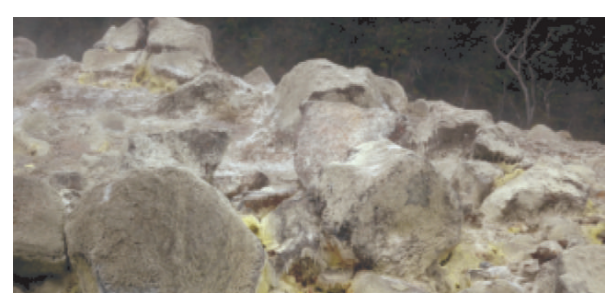

(a)

(b)

Intracellular $\mathrm{H}_{2} \mathrm{~S}$

(1) Production

(2) Storage

(3) Degradation

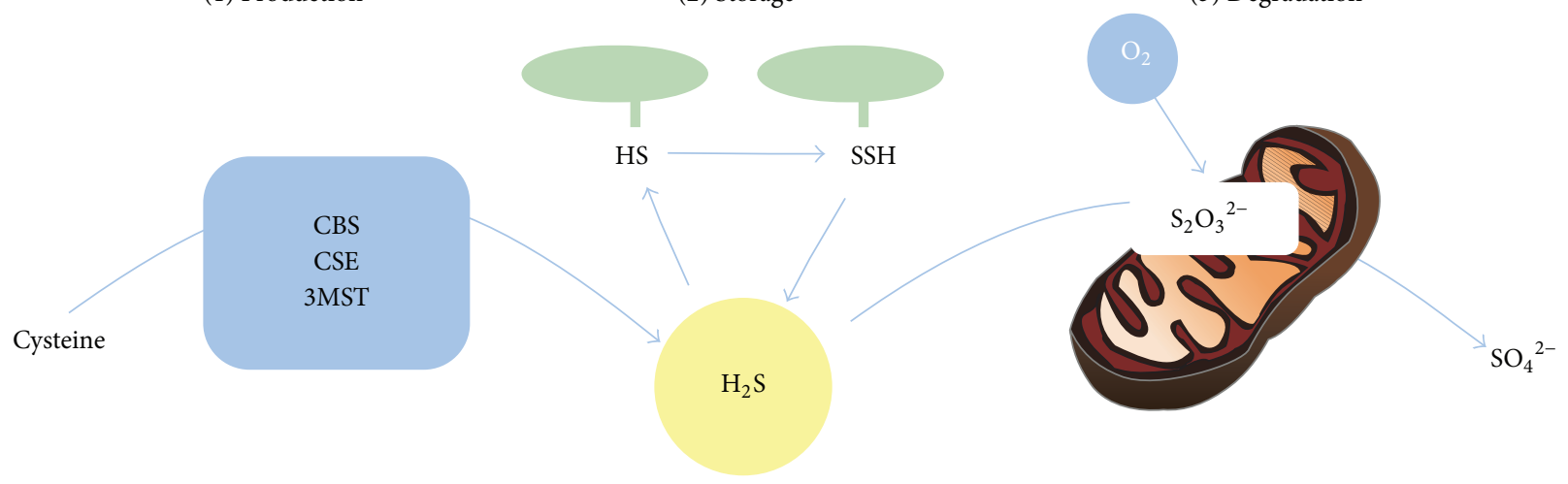

(c)

Figure 1: Sources of hydrogen sulfide. (a) Environmental hydrogen sulfide $\left(\mathrm{H}_{2} \mathrm{~S}\right)$ occurs due to geothermal activities such as volcanoes, sulfur deposits, or sulfur springs. The pictures show the Halema'uma'u crater (top) and sulfur deposit (bottom) on Hawaii Big Island. (b) Microbial production of $\mathrm{H}_{2} \mathrm{~S}$. Sulfate-reducing bacteria dissimilate sulfate into $\mathrm{H}_{2} \mathrm{~S}$ via dissimilatory sulfite reductase (DSR). Mesophilic bacteria use orthologues of the mammalian $\mathrm{H}_{2} \mathrm{~S}$-generating enzymes cystathionine- $\beta$-synthase (CBS), cystathionine- $\gamma$-lyase (CSE), and 3mercaptopyruvate sulfurtransferase (3MST) in order to generate $\mathrm{H}_{2} \mathrm{~S}$ from cysteine. (c) Mammalian cells produce $\mathrm{H}_{2} \mathrm{~S}$ from cysteine via CBS, CSE, and $3 \mathrm{MST}$ (1). $\mathrm{H}_{2} \mathrm{~S}$ can be stored in a reductant-labile intracellular pool as bound sulfane sulfur (2). The degradation of $\mathrm{H}_{2} \mathrm{~S}$ occurs via oxidative metabolic pathways in mitochondria (3).

the conversion of cysteine to 3-mercaptopyruvate and $\mathrm{H}_{2} \mathrm{~S}$, respectively $[4,9,20]$.

In addition, there is enzyme-free generation of $\mathrm{H}_{2} \mathrm{~S}$; however, this represents only a minor source of this gasotransmitter. Here, oxidation of sulfide produces thiosulfate, which in turn interacts with intracellular thiols such as GSH to release $\mathrm{H}_{2} \mathrm{~S}$.

(2) Intracellular $\mathrm{H}_{2} \mathrm{~S}$-Storage. Enzymatically produced $\mathrm{H}_{2} \mathrm{~S}$ can be intracellularly stored as bound sulfane sulfur [18]. This occurs by the oxidative formation of hydrodisulfides or persulfides, for example, by modification of the sulfur of cysteine residues in proteins, which establish a reductantlabile pool of sulfane sulfur $[18,21]$. A study by Shibuya and colleagues demonstrated that HEK293-F cells expressing 3MST contained larger amounts of sulfane sulfur than nontransfected cells or cells expressing enzymatically inactive 3MST [22]. This indicates that enzymatically produced $\mathrm{H}_{2} \mathrm{~S}$ is transformed into bound sulfane sulfur, thereby reducing the concentration of free intracellular $\mathrm{H}_{2} \mathrm{~S}$.

(3) Mitochondrial $\mathrm{H}_{2} \mathrm{~S}$-Degradation. $\mathrm{H}_{2} \mathrm{~S}$ affects mitochondrial respiration by inhibiting cytochrome $c$ oxidase [2] with an $\mathrm{IC}_{50}$ value of $0.32 \mu \mathrm{M}$ in colonic epithelial cell 
TABLE 1: $\mathrm{H}_{2} \mathrm{~S}$-producing bacteria of the digestive tract.

\begin{tabular}{|c|c|c|c|}
\hline Bacteria genus & Location & Process & References \\
\hline Veillonella & Oral cavity and stomach & $\begin{array}{c}\text { Metabolism of } \\
\text { carbohydrates/lactate }\end{array}$ & $\begin{array}{l}{[23]} \\
{[24]}\end{array}$ \\
\hline Actinomyces & Oral cavity and small intestine & Metabolism of lactate & $\begin{array}{l}{[23]} \\
{[24]} \\
\end{array}$ \\
\hline Prevotella & Oral cavity & $\begin{array}{l}\text { Metabolism of short-chain } \\
\text { fatty acids }\end{array}$ & $\begin{array}{l}{[23]} \\
{[24]}\end{array}$ \\
\hline $\begin{array}{l}\text { Desulfosarcina, } \\
\text { Desulfotomaculum, } \\
\text { Desulfonema, } \\
\text { Desulfovibrio (Desulfomonas), } \\
\text { Desulfococcus, } \\
\text { Desulfobacter }\end{array}$ & Human and animal colon & $\begin{array}{l}\text { Reduction of sulfate or } \\
\text { other oxidized sulfur } \\
\text { compounds using } \mathrm{H}_{2} \text { or } \\
\text { lactate }\end{array}$ & $\begin{array}{l}{[25]} \\
{[26]} \\
{[14]}\end{array}$ \\
\hline
\end{tabular}

homogenates [27]. Despite this finding, colonic epithelial cells are surprisingly resistant to even millimolar $\mathrm{H}_{2} \mathrm{~S}$ concentrations $[13,27]$ due to a detoxifying sulfide metabolism [13]. Remarkably, low (micromolar) concentrations of $\mathrm{H}_{2} \mathrm{~S}$ are even able to stimulate cellular respiration and represent an energy substrate for epithelial cells (for excellent review see [13]). $\mathrm{H}_{2} \mathrm{~S}$ is metabolized in mitochondria by the sulfide oxidation pathway $[18,28]$. In the presence of oxygen, sulfide:quinone oxidoreductases (SQR) oxidize $\mathrm{H}_{2} \mathrm{~S}$ to persulfide which is subsequently oxidized into sulfite via dioxygenase. Sulfite is further transferred into thiosulfate by rhodanese. Thiosulfate reductase and sulfite oxidase eventually metabolize thiosulfate into sulfate which is excreted. Interestingly, epithelial tissues which are predominantly exposed to $\mathrm{H}_{2} \mathrm{~S}$, such as colon epithelia, have a particular high metabolic, $\mathrm{H}_{2} \mathrm{~S}$-detoxifying capacity $[29,30]$.

The oxidative metabolism of $\mathrm{H}_{2} \mathrm{~S}$ in mitochondria implies that concentrations of free $\mathrm{H}_{2} \mathrm{~S}$ in normoxic tissues are low. The group of Olson demonstrated with $\mathrm{H}_{2} \mathrm{~S}$-specific amperometric sensors that endogenous $\mathrm{H}_{2} \mathrm{~S}$ production inversely correlates with oxygen concentrations [28, 31-33]. Hence, significant amounts of $\mathrm{H}_{2} \mathrm{~S}$ are only produced in anoxic environments and rapidly disappear in the presence of oxygen. This dynamic relationship between oxygen and $\mathrm{H}_{2} \mathrm{~S}$ indicates the necessity to maintain free $\mathrm{H}_{2} \mathrm{~S}$ concentrations low and, furthermore, led to the hypothesis that $\mathrm{H}_{2} \mathrm{~S}$ might be a cellular oxygen sensor $[28,34,35]$.

In sum, recent evidence suggests that there is a dynamic intracellular life-cycle of $\mathrm{H}_{2} \mathrm{~S}$. Its enzymatic production is antagonized by storage as bound sulfane sulfur and oxidative metabolism, thereby limiting the concentration of free $\mathrm{H}_{2} \mathrm{~S}$ to the submicromolar range $[36,37]$. Aside from the intracellular biochemical mechanisms to maintain low $\mathrm{H}_{2} \mathrm{~S}$ concentrations, there are epithelial mechanisms which prevent the exposure to potentially dangerous, high $\mathrm{H}_{2} \mathrm{~S}$ concentrations. This will be described in the next sections.

\section{Epithelial Reactions to $\mathrm{H}_{2} \mathrm{~S}$}

Similar to nervous, connective and muscle tissues, epithelia are a basic type of animal tissue. They are continuous sheets of tightly packed cells lining the surfaces and cavities of the body [38]. Epithelial cells are attached to each other by protein complexes such as tight junctions. The structure of an epithelium depends on the morphology of its cells and on the amount of cell layers it is made of. In monolayer epithelia (also called simple epithelia) the cells rest on the basal membrane. Flat and scale-like cells are characteristic of simple squamous epithelia. Cube-shaped cells constitute the simple cuboidal epithelium while simple columnar epithelia (gastrointestinal tract) are built of column-shaped cells. The cell nuclei may be disposed at different levels allowing for a pseudocellular stratification, a characteristic of the pseudostratified columnar epithelium which can be ciliated (trachea, upper respiratory tract) or not (penile urethra). When made of many layers, the epithelium is qualified as "stratified." Here, the shape of the upper most cells determines the type of epithelium. Hence, stratified squamous keratinized (skin) or not (oesophagus), stratified cuboidal (ducts of sweat glands), or stratified columnar (conjunctiva) epithelia can be distinguished. The lower most cell layers may comprise different types of cells. A further characteristic of stratified epithelia, besides keratinization, is their ability to contract and stretch. For the latter, they are called transitional epithelia (urothelium).

Epithelia are multifunctional structures which protect from mechanical forces or physical trauma, from desiccation or toxins. They act as barriers against pathogens, regulating exchanges of, for example, water and electrolytes between the milieu intérieur and the milieu extérieur. The epithelia of the lung or the digestive tract are especially faced with building a protective barrier towards the outer environment on the one hand and at the same time allowing for efficient exchange, such as the respiratory gases or food components, on the other. Vectorial transport of electrolytes and water is a fundamental feature of these epithelia, regulating the diffusion barrier for respiratory gases in the lung, or exchanging nutrients and water from intestinal content. Furthermore, these epithelia use secretory mechanisms as a defence reaction against potentially harmful substances by flushing their outer surfaces. Hence, the epithelial electrolyte and water transport machinery represents both a key feature for normal physiology of these organs and primary defence mechanism. In the following section we discuss the impact of $\mathrm{H}_{2} \mathrm{~S}$, 


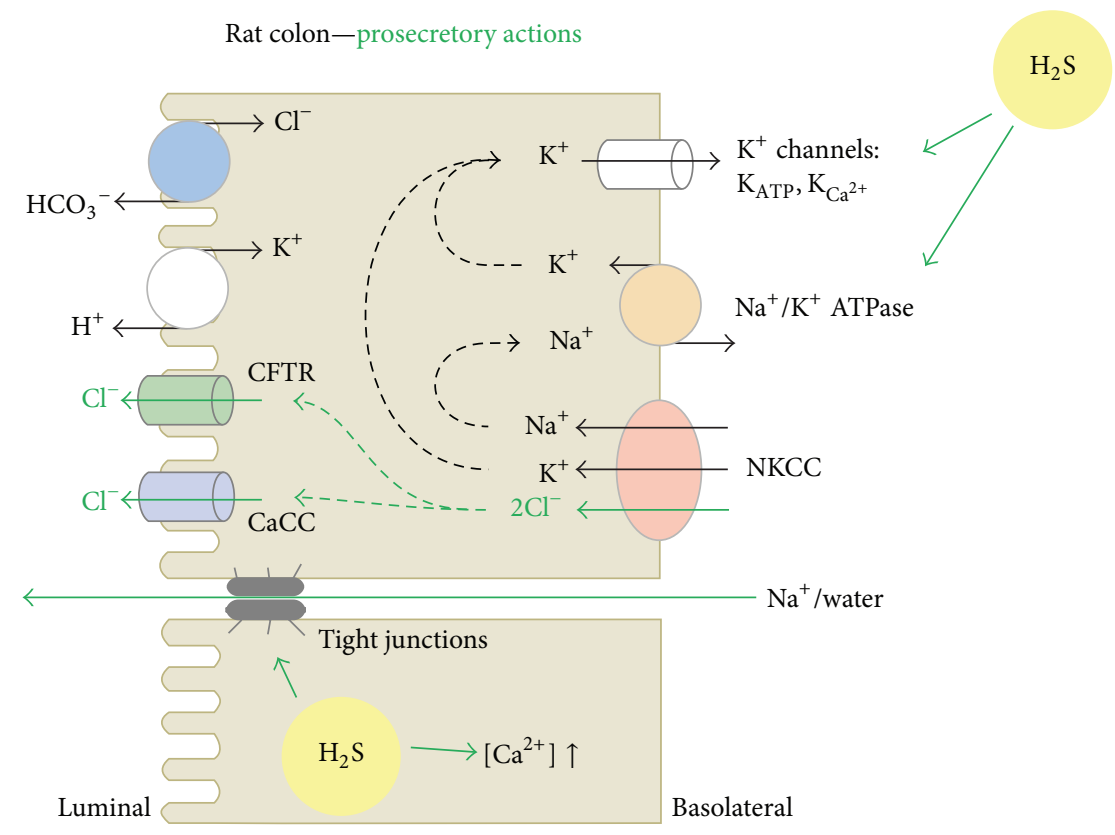

FIGURE 2: Epithelial ion transport responses to exogenous hydrogen sulfide in rat colon. Channels and transport mechanisms activated by $\mathrm{H}_{2} \mathrm{~S}$ in the rat colonic epithelium. Anion $\left(\mathrm{Cl}^{-}\right)$secretion through the cystic fibrosis transmembrane conductance regulator (CFTR) or calciumdependent chloride channels $(\mathrm{CaCC})$ is enabled after building up a cytosolic anion potential, which results from the activation of basolateral transporters notably: the $\mathrm{Na}^{+} / \mathrm{K}^{+}$-ATPase maintaining the $\mathrm{K}^{+}$concentration gradient between the intracellular and the extracellular spaces; the $\mathrm{Ca}^{2+}$-dependent $\left(\mathrm{K}_{\mathrm{Ca}^{2+}}\right)$ and ATP-sensitive $\left(\mathrm{K}_{\mathrm{ATP}}\right) \mathrm{K}^{+}$channels, responsible for the driving force allowing for uptake of $\mathrm{Cl}^{-}$via the basolateral $\mathrm{Na}^{+}-\mathrm{K}^{+}-\mathrm{Cl}^{-}$cotransporter type 1 (NKCC1). $\mathrm{H}_{2} \mathrm{~S}$ donors induce activation of the $\mathrm{Na}^{+} / \mathrm{K}^{+}$-ATPase and basolateral $\mathrm{K}^{+}$conductance, enabling intracellular accumulation of $\mathrm{Cl}^{-}$, which will be secreted via the CFTR or CaCC. Also, the apical $\mathrm{Na}^{+} / \mathrm{Ca}^{2+}$ exchanger was activated in parallel with increase in paracellular permeability.

in both potentially harmful and physiological concentrations, on electrolyte and water transport mechanisms in intestinal and pulmonary epithelia.

\section{1. $\mathrm{H}_{2} \mathrm{~S}$ and Intestinal Epithelia}

3.1.1. Intestinal Epithelial Responses to Exogenous $\mathrm{H}_{2} \mathrm{~S}$. The intestinal epithelium fulfils the above mentioned epithelial functions, with a more or less secretory or absorptive profile depending on the segment. The determination of intestinal epithelial functions finds its origins in its cellular organization. Intestinal epithelia are organized into finger-like protrusions called villi, absent in the colon, and invaginations called crypts of Lieberkühn (short: crypts). Four types of cells constitute the intestinal epithelium: enterocytes, goblet cells, Paneth cells, and enteroendocrine cells. The Paneth cells, absent in the colon, are located in the crypts and promote defence by their antimicrobial secretions. Also, pluripotent stem cells are located in the crypts; their mitosis generates the other cells, which migrate up the crypt-villus axis and differentiate. The goblet cells produce and secrete mucus, protecting against shear stress and chemical damage [38]. Enteroendocrine cells produce hormones or peptides for digestion or chemical sensors for digestive reflexes. Enterocytes are polarized cells representing the absorptive cell lineage. They carry an apical brush border which is responsible for enzymatic digestion, as well as ion, water, and nutrient uptake. These transport pathways may be transcellular passive (facilitated or not), active, or paracellular through cell junctions such as tight junctions.

Intestinal ion transport, which can be switched from absorption into secretion of water and electrolytes, is controlled by neurotransmitters and hormones, but also gasotransmitters such as $\mathrm{CO}, \mathrm{NO}, \mathrm{H}_{2} \mathrm{~S}$, and nitroxyl (HNO) [39, 40].

The colonic epithelium absorbs water and electrolytes under basal conditions; however, distention of the gut wall by intestinal content induces electrolyte secretion in order to generate a fluid film which facilitates the protrusion of the content. The switch to secretion is also observed after exposure of the epithelium to bacterial products and observed in the development of secretory diarrhoea under pathophysiological conditions. Secretion by the colonic epithelium is predominantly driven by a transepithelial secretion of chloride ions into the lumen, which osmotically facilitates liquid secretion. In order to secrete chloride across the apical membrane of the epithelial cells, the basolateral membrane has to establish a driving force for anion efflux via anion channels (e.g., cystic fibrosis transmembrane conductance regulator, CFTR, or $\mathrm{Ca}^{2+}$-sensitive chloride channels) located in the apical membrane (Figure 2). In the basolateral membrane, potassium channels generate the driving force for chloride secretion by maintaining the negative membrane potential which is dominated by a potassium diffusion potential [41, 


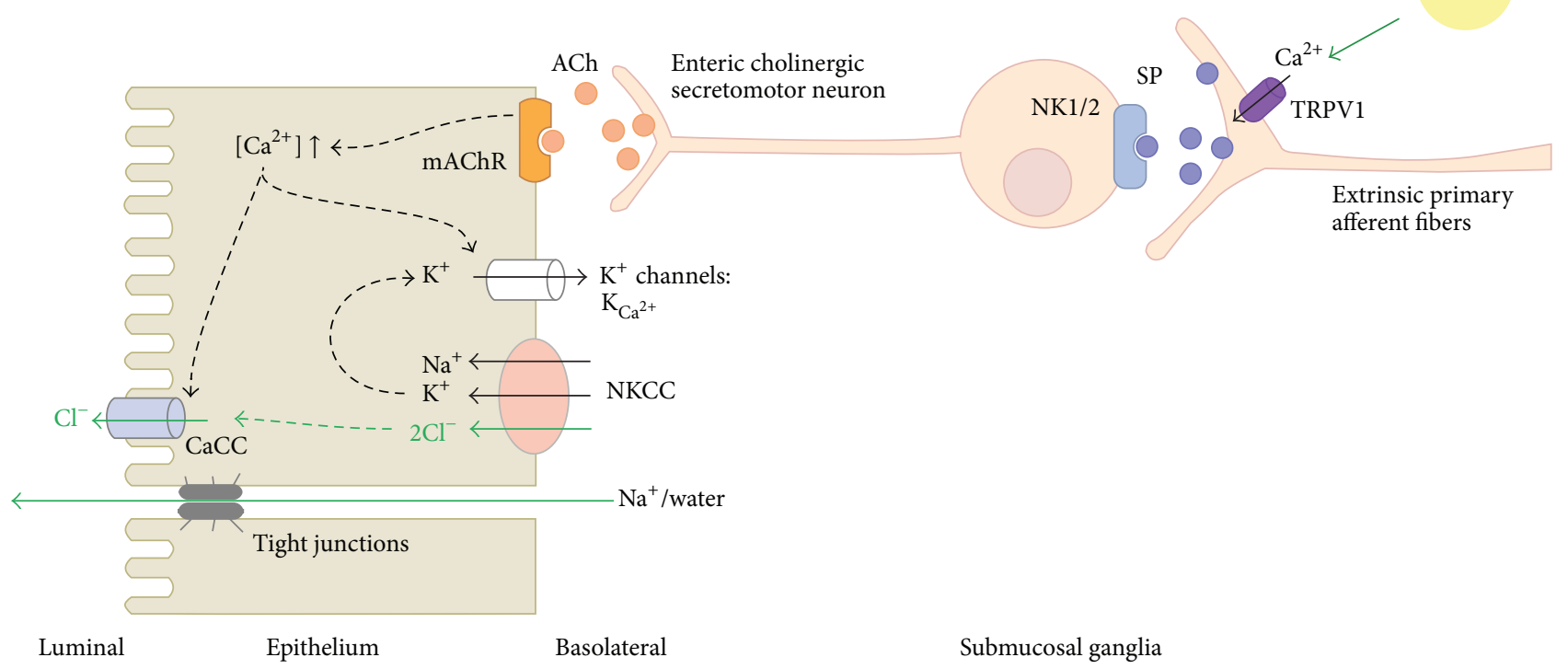

FIGURE 3: Exogenous hydrogen sulfide stimulates electrolyte secretion in human colon via activation of submucosal neurons. $\mathrm{H}_{2} \mathrm{~S}$ stimulates TRPV1 channels in extrinsic primary afferent fibres, which leads to the release of substance P (SP). SP binds to neurokinin receptors (NK) 1 and 2 of enteric cholinergic secretomotor neurons in submucosal ganglia. The subsequently released acetyl choline (ACh) binds to muscarinergic acetyl choline receptors $(\mathrm{mAChR})$ in the epithelial cells. This stimulates a rise in intracellular calcium concentrations which triggers electrolyte secretion by activating calcium-dependent chloride (CaCC) and potassium $\left(\mathrm{K}_{\mathrm{Ca}^{2+}}\right)$ channels.

42]. The $\mathrm{Na}^{+} / \mathrm{K}^{+}$-ATPase maintains the potassium concentration gradient between the intra- and the extracellular space as a prerequisite for the establishment of the potassium diffusion potential (Figure 2).

$\mathrm{H}_{2} \mathrm{~S}$ affects key ion transport processes within the colonic epithelium. In rat, guinea pig, and human colon preparations $\mathrm{H}_{2} \mathrm{~S}$ (applied by sulfur salts) elicits a secretory response [43-45]. In rat colon, $\mathrm{H}_{2} \mathrm{~S}$ activates the apical membrane $\mathrm{Na}^{+} / \mathrm{Ca}^{2+}$ exchanger extruding $\mathrm{Ca}^{2+}$ (Figure 2). It also induces an increase in cytosolic $\mathrm{Ca}^{2+}$ concentration as a result of the release of stored $\mathrm{Ca}^{2+}$ from intracellular organelles via $\mathrm{IP}_{3}$-receptors or ryanodine receptors (RyR). Cytosolic accumulation of $\mathrm{Ca}^{2+}$ triggers the opening of basolateral $\mathrm{Ca}^{2+}$-dependent potassium channels $\left(\mathrm{K}_{\mathrm{Ca}}\right)$. Furthermore, an ATP-sensitive basolateral potassium $\left(\mathrm{K}_{\mathrm{ATP}}\right)$ conductance is activated in the presence of $\mathrm{H}_{2} \mathrm{~S}$. The $\mathrm{K}_{\mathrm{ATP}}$ channels carrying this conductance may consist of the following combinations: Kir6.1/SUR1, Kir6.1/SUR2B, Kir6.2/SUR1, or Kir6.2/SUR2B [46]. They also exert a protective function against energy depletion as their inhibition by glibenclamide under this condition causes a huge increase in the colonic epithelium conductance [46]. The protective characteristic of $\mathrm{K}_{\text {ATP }}$ channels was also demonstrated in rats with colitis as their blockade with glibenclamide worsened the disease and increased mortality [47].

Both basolateral potassium conductance $\left(\mathrm{K}_{\mathrm{ATP}}\right.$ and $\left.\mathrm{K}_{\mathrm{Ca}}\right)$ build the driving force for apical chloride efflux (Figure 2). Furthermore, the $\mathrm{Na}^{+} / \mathrm{K}^{+}$-ATPase is also activated by $\mathrm{H}_{2} \mathrm{~S}$ [45]. In addition to the secretion of chloride, potassium is also secreted and the epithelial permeability increases [43, 48]. As a consequence of these secretion processes, sodium ions move paracellularly to the lumen (for electroneutrality) and water follows osmotically.

Aside from the direct effect of $\mathrm{H}_{2} \mathrm{~S}$ on ion channels and transporters within the epithelium, exogenous $\mathrm{H}_{2} \mathrm{~S}$ indirectly stimulates chloride secretion by activating secretomotor neurons in human and guinea pig colon mucosa/submucosa preparations [44] (Figure 3). This is supported by the facts that (1) the $\mathrm{H}_{2} \mathrm{~S}$-induced secretory response in these preparations is inhibited by tetrodotoxin and (2) it is absent in the human colon epithelial cell line T84 [44]. The reason for the different actions of $\mathrm{H}_{2} \mathrm{~S}$ in rat and human/guinea pig colon preparations is unknown but might be explained by differences in the species. In human/guinea pig colon, $\mathrm{H}_{2} \mathrm{~S}$ activates the transient receptor potential vanilloid receptor 1 (TRPV1) in extrinsic primary afferent fibres, which results in a release of substance P [49]. Substance P binds to neurokinin receptors $(\mathrm{NK})$ in enteric cholinergic secretomotor neurons [49]. The subsequent release of acetylcholine by these neurons stimulates epithelial chloride secretion via a muscarinergic receptor- and calcium-mediated signalling axis (Figure 3).

In addition to the described effects of $\mathrm{H}_{2} \mathrm{~S}$ on the secretion of chloride ions, $\mathrm{H}_{2} \mathrm{~S}$ activates bicarbonate secretion which in turn neutralizes excess acid produced in the gastrointestinal lumen thereby protecting from gastric or duodenal mucosa ulcers [50, 51]. Furthermore, $\mathrm{H}_{2} \mathrm{~S}$ increases mucus production from goblet cells, reversing inflammation-associated mucus deficiency [52].

The secretory response to exogenous $\mathrm{H}_{2} \mathrm{~S}$ could be interpreted as a defence mechanism of the intestinal epithelium which prevents potentially harmful $\mathrm{H}_{2} \mathrm{~S}$ concentrations 
which might exceed the oxidative capacities of the epithelial cells. Since the oxidative capacity is particularly high in intestinal epithelia [30] the secretory response would be triggered by rather high exogenous $\mathrm{H}_{2} \mathrm{~S}$ concentrations. In sum, exogenous $\mathrm{H}_{2} \mathrm{~S}$ triggers a secretory epithelial response in the intestine which prevents toxic effects of $\mathrm{H}_{2} \mathrm{~S}$ as well as onset of inflammatory processes by flushing the exogenous sources for $\mathrm{H}_{2} \mathrm{~S}$ from the epithelial wall.

\subsubsection{Endogenous $\mathrm{H}_{2} \mathrm{~S}$ Production in Intestinal Epithelia. Gut} tissue produces and releases $\mathrm{H}_{2} \mathrm{~S}[53]$ and the $\mathrm{H}_{2} \mathrm{~S}$-generating enzymes CBS and CSE have been found within rat colonic epithelium [43]. The local $\mathrm{H}_{2} \mathrm{~S}$ concentration within the intestinal wall is unknown but the production rate of $\mathrm{H}_{2} \mathrm{~S}$ in rat ileum is in the range of $12 \mathrm{nmol} / \mathrm{min} / \mathrm{g}$ tissue [54]. Consistent with the described prosecretory actions of $\mathrm{H}_{2} \mathrm{~S}$, inhibitors of CBS and CSE dose-dependently decreased basal anion secretion across rat distal colon preparations, indicating that endogenous $\mathrm{H}_{2} \mathrm{~S}$ production might contribute to basal (secretory) ion transport mechanisms in the epithelium [43]. These observations seem to contrast the principle of oxidative degradation of $\mathrm{H}_{2} \mathrm{~S}$ under normal physiological conditions (see Section 2.2.2); however, the environment of the gut might generate local, even subcellular anoxic milieus which would allow for enzymatic $\mathrm{H}_{2} \mathrm{~S}$ production. Whether or not endogenous $\mathrm{H}_{2} \mathrm{~S}$ influences basal secretory processes via the same mechanisms and ion channels/transporters as exogenous $\mathrm{H}_{2} \mathrm{~S}$ is unknown. Furthermore, the administration of the $\mathrm{H}_{2} \mathrm{~S}$ "precursor" L-cysteine stimulated a secretory response in guinea pig colon preparations, which was sensitive to CBS and CSE inhibitors as well as the TRP channel inhibitor capsaicin [44]. This indicates that the indirect secretory epithelial response in this preparation (see Section 3.1.1) does occur not only due to exogenous $\mathrm{H}_{2} \mathrm{~S}$, but also as a result of enhanced intracellular $\mathrm{H}_{2} \mathrm{~S}$ production in submucosal neurons. Whether such endogenous $\mathrm{H}_{2} \mathrm{~S}$ production in submucosal neurons occurs under physiological (normoxic) conditions and contributes to ion transport regulation is unknown.

3.1.3. $\mathrm{H}_{2} \mathrm{~S}$ in Intestinal Epithelia: Pharmacological Aspects. The local concentration of $\mathrm{H}_{2} \mathrm{~S}$ as well as the velocity of the $\mathrm{H}_{2} \mathrm{~S}$-generating pathway determines whether $\mathrm{H}_{2} \mathrm{~S}$ acts as a prosecretory (as described above) or as an antisecretory agent. This was demonstrated by assessing chloride secretion by rat enterocytes using different $\mathrm{H}_{2} \mathrm{~S}$-generating compounds: GYY4137 as a very slow releaser, L-cysteine and diallyl trisulfide as relatively slow releasers, and $\mathrm{NaHS}$ as a fast releaser. The last two compounds activated chloride secretion whereas L-cysteine and GYY4137 induced the opposite (antisecretory) effect [48]. Such concentration-dependent proabsorptive/prosecretory epithelial actions have already been described for NO and indicate that the kinetics of production, degradation, and even formation of reactive intermediates determines the physiological effects of gasotransmitters. These facts should be considered when evaluating (1) the contribution of (endogenous and exogenous) $\mathrm{H}_{2} \mathrm{~S}$ to the pathogenesis of diseases as well as (2) $\mathrm{H}_{2} \mathrm{~S}$-releasing molecules for therapeutic purposes.
For example, pro- and anti-inflammatory effects are ascribed to $\mathrm{H}_{2} \mathrm{~S}$ (for review, see [4]). In rat models of colitis, inflammation was resolved by NaHS, Lawesson's reagent, and diallyl trisulfide. These $\mathrm{H}_{2} \mathrm{~S}$ donors achieved such a positive action by downregulating the expression of proinflammatory cytokines (IL-1 $\beta$, TNF, INF $\gamma$, IL-12, and IL-13) and of chemokines (for review, see [7]). This is consistent with the observed therapeutic effects of, for example, the slow-release ATB-429 in a mouse model of colitis [55]. By contrast, other studies describe detrimental effects such as proinflammatory actions or impairment of gastrointestinal integrity [56-58].

In a rat model of colitis, the secretory response to $\mathrm{H}_{2} \mathrm{~S}$ was reduced in colon epithelial preparations. This reduction was prevented when the animals were fed on a S-reduced diet (which reduces microflora-mediated $\mathrm{H}_{2} \mathrm{~S}$ formation), but not by inhibitors of $\mathrm{H}_{2} \mathrm{~S}$-generating enzymes [59]. This is consistent with an enhanced number of SRBs and faecal $\mathrm{H}_{2} \mathrm{~S}$ production in patients with ulcerative colitis $[60,61]$. These findings indicate that alteration in exogenous, that is, colonic, microflora-derived $\mathrm{H}_{2} \mathrm{~S}$, determines the efficacy of $\mathrm{H}_{2} \mathrm{~S}$-liberating molecules in diseased tissues. This appears to be reasoned in a desensitisation of the intestinal epithelium to repeated exposure to $\mathrm{H}_{2} \mathrm{~S}$ [43]. Again, this example demonstrates that the kinetics of $\mathrm{H}_{2} \mathrm{~S}$ production and local concentration are important determinants of epithelial reactions to this molecule.

\section{2. $\mathrm{H}_{2} \mathrm{~S}$ and Pulmonary Epithelia}

3.2.1. Pulmonary Epithelial Responses to Exogenous $\mathrm{H}_{2} \mathrm{~S}$. In contrast to secretory actions of $\mathrm{H}_{2} \mathrm{~S}$ in the intestine, a growing body of evidence suggests that $\mathrm{H}_{2} \mathrm{~S}$ inhibits epithelial electrolyte absorption in a variety of tissues and species [33, 62-68], including epithelia of the lung. Electrolyte absorption by pulmonary epithelial cells is facilitated by the activity of basolaterally localised $\mathrm{Na}^{+} / \mathrm{K}^{+}$-ATPases which establish an electrochemical driving force for the entry of sodium ions through cation channels and/or transporters in the apical epithelial membrane [69]. The concerted action of these apical entry pathways and basolateral $\mathrm{Na}^{+} / \mathrm{K}^{+}$-ATPases generates a vectorial absorption of sodium ions across the epithelium. Consequently, sodium absorption facilitates the paracellular absorption of chloride ions and water (Figure 4).

The rate-limiting step for sodium absorption in many vertebrate epithelia including those of the lungs is the epithelial sodium channel (ENaC) [70-73]. Experimental evidence from lung epithelial preparations suggests that exogenous $\mathrm{H}_{2} \mathrm{~S}$ reduces $\mathrm{ENaC}$-mediated epithelial electrolyte absorption (Figure 4). $\mathrm{H}_{2} \mathrm{~S}$-releasing compounds such as the sulfur salts $\mathrm{NaHS}$ and $\mathrm{Na}_{2} \mathrm{~S}$ decreased basal ENaC-mediated sodium absorption in airway epithelial preparations from pigs and mice [62], as well as distal lung tissues from rats [33] and amphibians [63]. Consistent with the concept that lung liquid clearance largely depends on $\mathrm{ENaC}$-mediated sodium transport [74-76], the sulfur salts decreased the basal rate of transepithelial liquid absorption in rat lungs [33, 68]. A decreased capacity to absorb excess lung liquid would facilitate the formation of liquid accumulation in lungs. Mice 


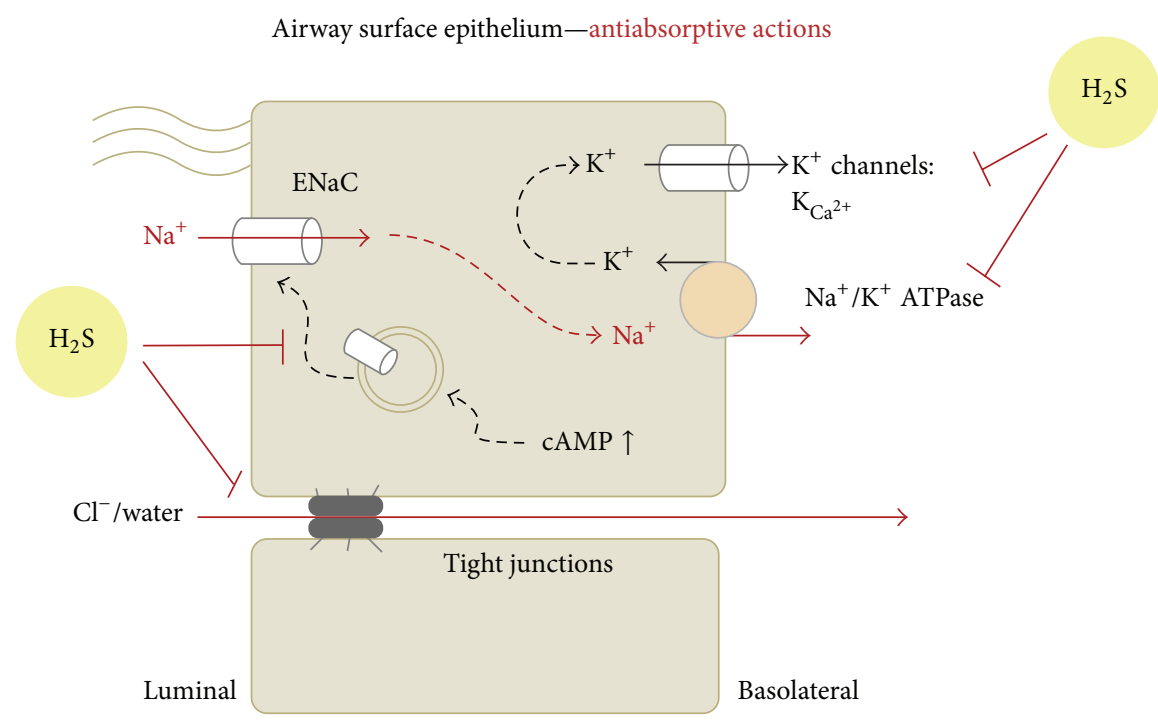

FIGURE 4: Airway epithelial ion transport responses to exogenous hydrogen sulfide. In airway surface epithelia, $\mathrm{H}_{2} \mathrm{~S}$ decreases basal absorption of $\mathrm{Na}^{+}$and eventually water by decreasing the electrochemical driving forces for apical entry of $\mathrm{Na}^{+}$through epithelial sodium channels (ENaC). This occurs by inhibition of the basolateral $\mathrm{Na}^{+} / \mathrm{K}^{+}$-ATPase as well as $\mathrm{K}_{\mathrm{Ca}^{2+}}$ channels. Furthermore, exogenous $\mathrm{H}_{2} \mathrm{~S}$ prevents the translocation of subapical vesicles containing ENaCs to the membrane thereby abrogating the action of proabsorptive, cAMP-dependent stimuli.

and rats develop such pulmonary oedema after exposure to exogenous $\mathrm{H}_{2} \mathrm{~S}[68,77,78]$. Furthermore, pulmonary oedema formation is characteristic for patients who suffer from acute $\mathrm{H}_{2} \mathrm{~S}$ poisoning [79], thus providing further evidence that exogenous $\mathrm{H}_{2} \mathrm{~S}$ reduces epithelial sodium and liquid absorption in lungs.

The precise mechanism how ENaC-mediated epithelial sodium absorption is impaired by $\mathrm{H}_{2} \mathrm{~S}$ has not been completely clarified. Patch-Clamp and heterologous expression experiments revealed that there is no direct effect of acute $\mathrm{H}_{2} \mathrm{~S}$ exposure on ENaC activity $[62,66,67]$. By contrast, long-term exposure to $\mathrm{H}_{2} \mathrm{~S}$ (NaHS) reduces the expression of the $\mathrm{ENaC} \alpha$-subunit by ERK1/2 mediated signalling [68]. However, the observed inhibition of ENaC-mediated epithelial sodium absorption by $\mathrm{H}_{2} \mathrm{~S}$ occurs too fast (within minutes) $[33,62,63]$ to be explained by changes in gene expression of sodium transporting molecules. As mentioned above, the electrochemical driving force for apical sodium entry through $\mathrm{ENaC}$ is generated by the basolateral $\mathrm{Na}^{+} / \mathrm{K}^{+}$ATPase. Apical membrane permeabilisation studies revealed that the activity of the $\mathrm{Na}^{+} / \mathrm{K}^{+}$-ATPase is reduced by $\mathrm{H}_{2} \mathrm{~S}$ $[62,63]$ (Figure 4). As described, the $\mathrm{Na}^{+} / \mathrm{K}^{+}$-ATPase is also influenced by $\mathrm{H}_{2} \mathrm{~S}$ in rat distal colon epithelia [45]. Furthermore, it is speculated that $\mathrm{H}_{2} \mathrm{~S}$-induced inhibition of sodium-uptake in larval zebrafish might be due to impaired $\mathrm{Na}^{+} / \mathrm{K}^{+}$-ATPase activity [65], further indicating that this enzyme is a molecular target for $\mathrm{H}_{2} \mathrm{~S}$.

Aside from the $\mathrm{Na}^{+} / \mathrm{K}^{+}$-ATPase, basolateral potassium channels contribute to the electrochemical driving force for sodium absorption by maintaining a negative membrane potential which facilitates cation influx at the apical epithelial plasma membrane. It was demonstrated that $\mathrm{H}_{2} \mathrm{~S}$ inhibits basolateral potassium channels in lung epithelia $[62,63]$
(Figure 4). Inhibitor studies suggest that $\mathrm{K}_{\mathrm{Ca}}$ channels are likely targeted by $\mathrm{H}_{2} \mathrm{~S}$; however, the precise type of basolateral potassium channel has yet to be identified. Inhibition of potassium channels as well as the $\mathrm{Na}^{+} / \mathrm{K}^{+}$-ATPase impairs the electrochemical gradient which is necessary for ENaCmediated sodium influx and thereby reduces overall transepithelial sodium and, consequently, liquid absorption.

How $\mathrm{H}_{2} \mathrm{~S}$ leads to a decreased activity of these basolateral transporting molecules remains unknown. As mentioned above, the rapid effects of $\mathrm{H}_{2} \mathrm{~S}$ suggest changes in the activity of the transporting molecules rather than changes in their expression levels. This might be achieved by either changing their transport activity rates or, alternatively, their abundance in the basolateral plasma membrane.

In rat renal tubular epithelial cells, NaHS induces endocytosis of the $\mathrm{Na}^{+} / \mathrm{K}^{+}$-ATPase thereby inhibiting renal sodium absorption [64]. This occurs via a signalling cascade which is initiated by activation of the epidermal growth factor receptor by $\mathrm{H}_{2} \mathrm{~S}$. In $\mathrm{H} 441$ lung epithelial cells, there is no change in membrane abundance of the $\mathrm{Na}^{+} / \mathrm{K}^{+}$-ATPase within the time course of sodium transport inhibition by $\mathrm{H}_{2} \mathrm{~S}$ [62], indicating that in lung epithelia $\mathrm{H}_{2} \mathrm{~S}$ rather interferes with the transport activity of this enzyme.

Activity changes of transport proteins might be achieved by a posttranslational modification due to $\mathrm{H}_{2} \mathrm{~S}$. Initially it was suggested that $\mathrm{H}_{2} \mathrm{~S}$ is able to directly modify thiol groups in proteins (including $\mathrm{K}_{\mathrm{ATP}}$ channels), a mechanism which was referred to as S-sulfhydration [80, 81], although persulfidation is the more correct term [82]. Recently it became clear that $\mathrm{H}_{2} \mathrm{~S}$ alone is not able to modify thiol groups, but derivatives of $\mathrm{H}_{2} \mathrm{~S}$ such as polysulfides [83] or reaction products of $\mathrm{H}_{2} \mathrm{~S}$ and NO such as nitroxyl (HNO) are able to do so [82]. Elegant work by Eberhardt and colleagues recently dissected 
a mechanism underlying the activation of a member of the TRP channel family (TRPA1) by $\mathrm{H}_{2} \mathrm{~S}$. These authors observed that $\mathrm{HNO}$, which is formed by a redox reaction between $\mathrm{H}_{2} \mathrm{~S}$ and $\mathrm{NO}$, induced calcium influx into neurons from dorsal root ganglia of wild type, but not TRPA1-knock-out mice [84]. The primary targets for HNO are thiols [85] and the Nterminal region of TRPA1 contains cysteine residues which are necessary for activation of the channel by sulfhydrylreactive agents $[86,87]$. Mutation of these residues to lysine prevented the activation of human TRPA1 by HNO [84]. Furthermore, the authors demonstrated that HNO induces a formation of disulfide bonds and suggest a model by which disulfide bond formation between two cysteine pairs induces a conformational change which leads to channel opening [84].

Whether a similar mechanism would also account for the observed inhibition of the $\mathrm{Na}^{+} / \mathrm{K}^{+}$-ATPase and basolateral potassium channels in lung epithelia remains to be investigated. Interestingly, NO also inhibits basolateral transporting molecules in H441 lung epithelial cells, with similar kinetics to $\mathrm{H}_{2} \mathrm{~S}$ [88], and posttranslational thiol-modification modulates the activity of the $\mathrm{Na}^{+} / \mathrm{K}^{+}$-ATPase [89]. Furthermore, $\mathrm{HNO}$ was recently shown to influence the $\mathrm{Na}^{+} / \mathrm{K}^{+}$ATPase and basolateral potassium channels in distal rat colon epithelia [40], suggesting that these molecules represent molecular targets for reactive derivatives of $\mathrm{H}_{2} \mathrm{~S}$. However, it has to be noted that $\mathrm{H}_{2} \mathrm{~S}$ stimulates the $\mathrm{Na}^{+} / \mathrm{K}^{+}$-ATPase in the rat colon, whereas an inhibition of the $\mathrm{Na}^{+} / \mathrm{K}^{+}$-ATPase was observed in airway surface epithelia. This discrepancy might be explained by variations in the $\mathrm{Na}^{+} / \mathrm{K}^{+}$-ATPase subunit composition. The $\mathrm{Na}^{+} / \mathrm{K}^{+}$-ATPase consists of core $\alpha$ and $\beta$-subunit, of which there are four and three isoforms, respectively [90]. In addition, these core $\alpha / \beta$-complexes assemble with an additional subunit of the FXYD protein family [91]. Tissue-dependent differences in the molecular $\mathrm{Na}^{+} / \mathrm{K}^{+}$-ATPase compositions might account for the different reactions to $\mathrm{H}_{2} \mathrm{~S}$. Furthermore, basolateral potassium channels indirectly influence $\mathrm{Na}^{+} / \mathrm{K}^{+}$-ATPase activity by either enhancing or diminishing basolateral potassium-recycling and hence activity of the $\mathrm{Na}^{+} / \mathrm{K}^{+}$-ATPase. It is possible that the potassium channel repertoire of the basolateral membrane indirectly contributes to the observed variety in responses to $\mathrm{H}_{2} \mathrm{~S}$.

Aside from the influence of $\mathrm{H}_{2} \mathrm{~S}$ on basal epithelial sodium transport processes, $\mathrm{H}_{2} \mathrm{~S}$ reduces the efficacy of proabsorptive stimuli. In lung epithelia, $\mathrm{H}_{2} \mathrm{~S}$ abrogated the stimulation of $\mathrm{ENaC}$-mediated sodium transport and lung liquid clearance by $\beta$-adrenergic receptor agonists [33]. This is the result of an impairment of the cAMP/protein kinase $\mathrm{A}$ signalling axis, although the molecular target for $\mathrm{H}_{2} \mathrm{~S}$ remains unknown. In amphibian A6 (renal) cells, $\mathrm{H}_{2} \mathrm{~S}$ prevented the activation of ENaC by reactive oxygen species [66] and advanced glycation end-products [67], likely due to antioxidative mechanisms.

In sum, the currently available data indicate antiabsorptive actions of exogenous $\mathrm{H}_{2} \mathrm{~S}$ on electrolyte absorbing pulmonary epithelia.
3.2.2. Endogenous $\mathrm{H}_{2} \mathrm{~S}$ Production in Pulmonary Epithelia. In the human respiratory system, CBS/CSE have been detected in nasal mucosa [92, 93], submucosal glands [92, 93], and human H441 airway epithelial cells [33]. 3MST has only been detected at the mRNA level in human $\mathrm{H} 441$ cells [33]. In rodents, CBS/CSE are present in mouse airway epithelium [94], whereas CSE/3MST but not CBS were detected in rat lung homogenates [95]. All three proteins are present in airways and alveoli of cow and sea lion lungs [31]. These data indicate that pulmonary epithelia contain $\mathrm{H}_{2} \mathrm{~S}$-generating pathways. Consistently, using $\mathrm{H}_{2} \mathrm{~S}$-specific amperometric sensors it was shown that rat lung homogenates [95] as well as H441 epithelial cell lysates [33] produce detectable amounts of $\mathrm{H}_{2} \mathrm{~S}$.

However, $\mathrm{H}_{2} \mathrm{~S}$ production is only detectable in the absence of oxygen (see Section 2.2.2). Consistently, inhibition of $\mathrm{H}_{2} \mathrm{~S}$-generating enzymes under normoxic conditions does not alter baseline sodium absorption by these cells [62]. This indicates that $\mathrm{H}_{2} \mathrm{~S}$ is not a basal regulator of pulmonary epithelial sodium transport processes and the observed inhibition of sodium and water absorption rather represents an epithelial reaction to either exogenous $\mathrm{H}_{2} \mathrm{~S}$ or deregulated endogenous $\mathrm{H}_{2} \mathrm{~S}$ generation under pathophysiological conditions.

\subsection{3. $\mathrm{H}_{2} \mathrm{~S}$ in Lung Epithelia: Physiological and Pathophysio-} logical Aspects. How can these findings be integrated into a physiological context? The antiabsorptive and prosecretory epithelial responses can be interpreted as an epithelial defence mechanism against potentially harmful $\mathrm{H}_{2} \mathrm{~S}$ concentrations which exceed the oxidative $\mathrm{H}_{2} \mathrm{~S}$-degrading capacities of the epithelial cells. Liquid accumulation at the luminal side of the epithelia would eliminate the potential sources of $\mathrm{H}_{2} \mathrm{~S}$ (such as microbiota) by "flushing" of epithelia-covered compartments.

The main epithelial defence mechanism in the lung is airway mucociliary clearance [96, 97], whereas in the distal, alveolar regions of the lungs, primary defence against potential pathogens is maintained by alveolar macrophages. The entire epithelial surface of the airways is covered by a thin film of liquid, the airway surface liquid (ASL). This ASL is composed of a liquid phase surrounding the cilia of the airway epithelial cells, the periciliary liquid (PCL), and a gel-like mucus layer on top of the PCL [98]. The mucus layer is a trap for inhaled particles and potential pathogens. Due to ciliary movement, the PCL as well as the mucus layer moves towards the larynx, thereby clearing the trapped particles/pathogens from the lungs. Mucus clearance depends on the degree of hydration of the mucus gel: an increase in ASL volume enhances mucociliary clearance [96, 97, 99]. Hence, mechanisms which result in hydration of the ASL will eventually strengthen mucociliary clearance and clear the pulmonary epithelial surface from potential pathogens. The ASL volume and, consequently, the degree of mucus hydration are regulated by liquid secretion and absorption across the pulmonary epithelium.

The liquid feeding the PCL/ASL is produced by submucosal glands [96], a process which depends on vectorial 
anion secretion by serous cells of the glands [97]. A recent study demonstrated that submucosal glands of pig tracheal epithelia secrete liquid upon exposure to bacteria such as Pseudomonas aeruginosa [100], thereby showing that liquid secretion and augmented mucociliary clearance are a primary defence mechanism in the airways. Whether or not $\mathrm{H}_{2} \mathrm{~S}$ elicits anion secretion in submucosal glands is currently unknown. In experiments addressing liquid secretion/absorption rates in fluid-filled rat lungs, there was no effect of $\mathrm{H}_{2} \mathrm{~S}$ over that of the ENaC-inhibitor amiloride, indicating that $\mathrm{H}_{2} \mathrm{~S}$ does not induce a detectable liquid secretion [33]. However, in this preparation the major liquid movements occur across the large surface of the alveolar regions. A potential contribution of gland secretion of the upper airways might be difficult to detect with this approach.

Aside from liquid secretion by submucosal glands, the surface epithelium of the airways is considered to absorb excess liquid [96]. This concept is supported by an anatomical view of the epithelia-covered lung structures. The alveolar surface of the human lung is by a magnitude of $10^{5}$ larger than that of the trachea [101]. Given that the epithelial surface liquid (alveolar liquid and ASL) is continuously transported towards the larynx, the volume of liquid lining the airway epithelia should also increase by the same magnitude. However, the height of the liquid layer lining the epithelia is relatively constant, indicating that excess volume is absorbed by the surface epithelial cells of the airways [101]. A reduction in epithelial sodium and liquid absorption would therefore result in a volume increase of the ASL. An in vitro approach using cultured human airway epithelia demonstrated that volume increase of the ASL results in a higher rate of mucus transport [102]. Furthermore, patients with the hereditary disease Pseudohypoaldosteronism Type 1 have a reduced ENaC activity in the airways and thus an increased ASL volume [99]. Consistently, these patients display a mucus transport rate which is profoundly above that of normal subjects [99]. This example demonstrates that a reduction in $\mathrm{ENaC}$-mediated sodium absorption eventually results in an increased mucociliary clearance and would therefore be consistent with the idea of an $\mathrm{H}_{2} \mathrm{~S}$-induced "defence-flushing" of epithelial surfaces. The occurrence of rhinorrhoea during exposure to $\mathrm{H}_{2} \mathrm{~S}$ [103] is consistent with an increased amount of surface liquid in the respiratory system. Furthermore, the formation of rhinorrhoea or, in the distal lung, pulmonary oedema due to $\mathrm{H}_{2} \mathrm{~S}$ poisoning might be interpreted as a hyperresponsive epithelial defence reaction to exogenous $\mathrm{H}_{2} \mathrm{~S}$.

\section{Conclusion and Perspective}

The herein reviewed findings teach a concept by which physiological effects elicited by $\mathrm{H}_{2} \mathrm{~S}$ critically depend on its concentration as well as kinetics of its production and metabolism. In accordance with Paracelsus' principle, the local concentration is the critical factor which allows the separation of physiology and toxicology of $\mathrm{H}_{2} \mathrm{~S}$. The precise determination of local $\mathrm{H}_{2} \mathrm{~S}$ concentrations is still a major technical challenge (for review see $[36,37]$ ) and hampers the classification of toxic, physiological, and beneficial roles for this molecule.

The currently available data on (1) the biochemistry of endogenous $\mathrm{H}_{2} \mathrm{~S}$ production; (2) its correlation with oxygen availability; and (3) epithelial reactions to exogenous $\mathrm{H}_{2} \mathrm{~S}$ suggest that normal physiology aims to maintain a low endogenous $\mathrm{H}_{2} \mathrm{~S}$ concentration which is likely in the submicromolar range. The future challenges will be to understand pathophysiological conditions, in which these systems are impaired, and the precise determination of concentration windows which allow for pharmacological interference. Furthermore, the contribution of exogenous (i.e., microbiotaderived) $\mathrm{H}_{2} \mathrm{~S}$ in experimental studies should be taken into consideration. At this stage it appears most suitable to close with the introductory quote: "All things are poisons, for there is nothing without poisonous qualities. It is only the dose which makes a thing poison."

\section{Conflict of Interests}

The authors declare that there is no conflict of interests regarding the publication of this paper.

\section{Acknowledgments}

The authors would like to thank Pawel Piotr Szczesniak and Fabrizio Santangelo for helpful comments and discussions. Professor Martin Diener is acknowledged for outstanding support. Mike Althaus is supported by a grant from the German Research Foundation (DFG, AL1453/1-2).

\section{References}

[1] R. J. Reiffenstein, W. C. Hulbert, and S. H. Roth, “Toxicology of hydrogen sulfide," Annual Review of Pharmacology and Toxicology, vol. 32, pp. 109-134, 1992.

[2] L. C. Petersen, "The effect of inhibitors on the oxygen kinetics of cytochrome c oxidase," Biochimica et Biophysica Acta (BBA)Bioenergetics, vol. 460, no. 2, pp. 299-307, 1977.

[3] J. P. Collman, S. Ghosh, A. Dey, and R. A. Decréau, "Using a functional enzyme model to understand the chemistry behind hydrogen sulfide induced hibernation," Proceedings of the National Academy of Sciences of the United States of America, vol. 106, no. 52, pp. 22090-22095, 2009.

[4] R. Wang, "Physiological implications of hydrogen sulfide: a whiff exploration that blossomed," Physiological Reviews, vol. 92, no. 2, pp. 791-896, 2012.

[5] R. Wang, "Two's company, three's a crowd: can $\mathrm{H}_{2} \mathrm{~S}$ be the third endogenous gaseous transmitter?" The FASEB Journal, vol. 16, no. 13, pp. 1792-1798, 2002.

[6] K. Kashfi and K. R. Olson, "Biology and therapeutic potential of hydrogen sulfide and hydrogen sulfide-releasing chimeras," Biochemical Pharmacology, vol. 85, no. 5, pp. 689-703, 2013.

[7] J. L. Wallace and R. Wang, "Hydrogen sulfide-based therapeutics: exploiting a unique but ubiquitous gasotransmitter," Nature Reviews Drug Discovery, vol. 14, no. 5, pp. 329-345, 2015.

[8] E. R. Deleon, G. F. Stoy, and K. R. Olson, "Passive loss of hydrogen sulfide in biological experiments," Analytical Biochemistry, vol. 421, no. 1, pp. 203-207, 2012. 
[9] C. Szabõ, "Hydrogen sulphide and its therapeutic potential," Nature Reviews Drug Discovery, vol. 6, no. 11, pp. 917-935, 2007.

[10] J. R. D. Nelson, J. D. R. Lide, and A. A. Maryott, Selected Values of Electric Dipole Moments for Molecules in the Gas Phase, vol. 10 of NSRDS-NBS, U.S. Government Printing Office, Washington, DC, USA, 1967.

[11] J. C. Mathai, A. Missner, P. Kügler et al., "No facilitator required for membrane transport of hydrogen sulfide," Proceedings of the National Academy of Sciences of the United States of America, vol. 106, no. 39, pp. 16633-16638, 2009.

[12] C. Willis, J. Cummings, G. Neale, and G. Gibson, "In vitro effects of mucin fermentation on the growth of human colonic sulphate-reducing bacteria," Anaerobe, vol. 2, pp. 117-122, 1996.

[13] F. Blachier, A.-M. Davila, S. Mimoun et al., "Luminal sulfide and large intestine mucosa: friend or foe?” Amino Acids, vol. 39, no. 2, pp. 335-347, 2010.

[14] P. D. Scanlan, F. Shanahan, and J. R. Marchesi, "Cultureindependent analysis of desulfovibrios in the human distal colon of healthy, colorectal cancer and polypectomized individuals," FEMS Microbiology Ecology, vol. 69, no. 2, pp. 213-221, 2009.

[15] K. Shatalin, E. Shatalina, A. Mironov, and E. Nudler, " $\mathrm{H}_{2} \mathrm{~S}$ : a universal defense against antibiotics in bacteria," Science, vol. 334, no. 6058, pp. 986-990, 2011.

[16] G. T. Macfarlane, G. R. Gibson, and J. H. Cummings, "Comparison of fermentation reactions in different regions of the human colon," Journal of Applied Bacteriology, vol. 72, no. 1, pp. 57-64, 1992.

[17] Z. J. Song, M. Y. Ng, Z.-W. Lee et al., "Hydrogen sulfide donors in research and drug development," MedChem Comm, vol. 5, no. 5, pp. 557-570, 2014.

[18] H. Kimura, "Metabolic turnover of hydrogen sulfide," Frontiers in Physiology, vol. 3, article 101, 2012.

[19] H. Kimura, "Physiological role of hydrogen sulfide and polysulfide in the central nervous system," Neurochemistry International, vol. 63, no. 5, pp. 492-497, 2013.

[20] C. E. Paulsen and K. S. Carroll, "Cysteine-mediated redox signaling: chemistry, biology, and tools for discovery," Chemical Reviews, vol. 113, no. 7, pp. 4633-4679, 2013.

[21] T. S. Bailey, L. N. Zakharov, and M. D. Pluth, "Understanding hydrogen sulfide storage: probing conditions for sulfide release from hydrodisulfides," Journal of the American Chemical Society, vol. 136, no. 30, pp. 10573-10576, 2014.

[22] N. Shibuya, M. Tanaka, M. Yoshida et al., "3-Mercaptopyruvate sulfurtransferase produces hydrogen sulfide and bound sulfane sulfur in the brain," Antioxidants \& Redox Signaling, vol. 11, no. 4, pp. 703-714, 2009.

[23] J. Washio, T. Sato, T. Koseki, and N. Takahashi, "Hydrogen sulfide-producing bacteria in tongue biofilm and their relationship with oral malodour," Journal of Medical Microbiology, vol. 54, no. 9, pp. 889-895, 2005.

[24] I. Sekirov, S. L. Russell, L. Caetano M Antunes, and B. B. Finlay, "Gut microbiota in health and disease," Physiological Reviews, vol. 90, no. 3, pp. 859-904, 2010.

[25] T. Florin, G. Neale, G. R. Gibson, S. U. Christl, and J. H. Cummings, "Metabolism of dietary sulphate: absorption and excretion in humans," Gut, vol. 32, no. 7, pp. 766-773, 1991.

[26] D. H. Bergey and J. G. Holt, Bergey's Manual of Determinative Bacteriology, Williams \& Wilkins, Baltimore, Md, USA, 9th edition, 1993.
[27] X. Leschelle, M. Goubern, M. Andriamihaja et al., "Adaptative metabolic response of human colonic epithelial cells to the adverse effects of the luminal compound sulfide," Biochimica et Biophysica Acta-General Subjects, vol. 1725, no. 2, pp. 201-212, 2005.

[28] K. R. Olson, "Hydrogen sulfide as an oxygen sensor," Clinical Chemistry and Laboratory Medicine, vol. 51, no. 3, pp. 623-632, 2013.

[29] J. Furne, J. Springfield, T. Koenig, E. DeMaster, and M. D. Levitt, "Oxidation of hydrogen sulfide and methanethiol to thiosulfate by rat tissues: a specialized function of the colonic mucosa," Biochemical Pharmacology, vol. 62, no. 2, pp. 255-259, 2001.

[30] S. Mimoun, M. Andriamihaja, C. Chaumontet et al., "Detoxification of $\mathrm{H}_{2} \mathrm{~S}$ by differentiated colonic epithelial cells: implication of the sulfide oxidizing unit and of the cell respiratory capacity," Antioxidants and Redox Signaling, vol. 17, no. 1, pp. 110, 2012.

[31] K. R. Olson, N. L. Whitfield, S. E. Bearden et al., "Hypoxic pulmonary vasodilation: a paradigm shift with a hydrogen sulfide mechanism," The American Journal of PhysiologyRegulatory Integrative and Comparative Physiology, vol. 298, no. 1, pp. R51-R60, 2010.

[32] R. A. Dombkowski, M. G. Naylor, E. Shoemaker et al., "Hydrogen sulfide $\left(\mathrm{H}_{2} \mathrm{~S}\right)$ and hypoxia inhibit salmonid gastrointestinal motility: evidence for $\mathrm{H}_{2} \mathrm{~S}$ as an oxygen sensor," Journal of Experimental Biology, vol. 214, no. 23, pp. 4030-4040, 2011.

[33] A. M. Agné, J. Baldin, A. R. Benjamin et al., "Hydrogen sulfide decreases $\beta$-adrenergic agonist-stimulated lung liquid clearance by inhibiting ENaC-mediated transepithelial sodium absorption," American Journal of Physiology-Regulatory, Integrative and Comparative Physiology, vol. 308, no. 7, pp. R636-R649, 2015.

[34] P. J. Kemp and V. Telezhkin, "Oxygen sensing by the carotid body: is it all just rotten eggs?" Antioxidants and Redox Signaling, vol. 20, no. 5, pp. 794-804, 2014.

[35] K. R. Olson, "Hydrogen sulfide as an oxygen sensor," Antioxidants \& Redox Signaling, vol. 22, no. 5, pp. 377-397, 2015.

[36] K. R. Olson, "Hydrogen sulfide: both feet on the gas and none on the brake?" Frontiers in Physiology, vol. 4, article 2, 2013.

[37] K. R. Olson, E. R. DeLeon, and F. Liu, "Controversies and conundrums in hydrogen sulfide biology," Nitric Oxide, vol. 41, pp. 11-26, 2014.

[38] L. G. van der Flier and H. Clevers, "Stem cells, self-renewal, and differentiation in the intestinal epithelium," Annual Review of Physiology, vol. 71, pp. 241-260, 2009.

[39] E. Pouokam, J. Steidle, and M. Diener, "Regulation of colonic ion transport by gasotransmitters," Biological and Pharmaceutical Bulletin, vol. 34, no. 6, pp. 789-793, 2011.

[40] E. Pouokam, A. Bell, and M. Diener, "Actions of Angeli's salt, a nitroxyl (HNO) donor, on ion transport across mucosasubmucosa preparations from rat distal colon," European Journal of Pharmacology, vol. 715, no. 1-3, pp. 133-141, 2013.

[41] D. Strabel and M. Diener, "Evidence against direct activation of chloride secretion by carbachol in the rat distal colon," European Journal of Pharmacology, vol. 274, no. 1-3, pp. 181-191, 1995.

[42] R. Warth and J. Barhanin, "Function of $\mathrm{K}+$ channels in the intestinal epithelium," Journal of Membrane Biology, vol. 193, no. 2, pp. 67-78, 2003.

[43] B. Hennig and M. Diener, "Actions of hydrogen sulphide on ion transport across rat distal colon," British Journal of Pharmacology, vol. 158, no. 5, pp. 1263-1275, 2009. 
[44] R. Schicho, D. Krueger, F. Zeller et al., "Hydrogen sulfide is a novel prosecretory neuromodulator in the Guinea-pig and human colon," Gastroenterology, vol. 131, no. 5, pp. 1542-1552, 2006.

[45] E. Pouokam and M. Diener, "Mechanisms of actions of hydrogen sulphide on rat distal colonic epithelium," British Journal of Pharmacology, vol. 162, no. 2, pp. 392-404, 2011.

[46] E. Pouokam, S. Bader, B. Brück, B. Schmidt, and M. Diener, "ATP-sensitive $\mathrm{K}^{+}$channels in rat colonic epithelium," Pflugers Archiv-European Journal of Physiology, vol. 465, no. 6, pp. 865877, 2013.

[47] J. L. Wallace, L. Vong, W. McKnight, M. Dicay, and G. R. Martin, "Endogenous and exogenous hydrogen sulfide promotes resolution of colitis in rats," Gastroenterology, vol. 137, no. 2, pp. 569.el578.e1, 2009.

[48] E. Pouokam and M. Diener, "Modulation of ion transport across rat distal colon by cysteine," Frontiers in Physiology, vol. 3, article 43, 2012.

[49] D. Krueger, M. Foerster, K. Mueller et al., "Signaling mechanisms involved in the intestinal pro-secretory actions of hydrogen sulfide," Neurogastroenterology \& Motility, vol. 22, no. 11, p. 1224-e320, 2010.

[50] K. Takeuchi, E. Aihara, M. Kimura, K. Dogishi, T. Hara, and S. Hayashi, "Gas mediators involved in modulating duodenal HCO3-secretion," Current Medicinal Chemistry, vol. 19, no. 1, pp. 43-54, 2012.

[51] R. W. Blackler, B. Gemici, A. Manko, and J. L. Wallace, "NSAID-gastroenteropathy: new aspects of pathogenesis and prevention," Current Opinion in Pharmacology, vol. 19, pp. 1116, 2014.

[52] J. Motta, K. L. Flannigan, T. A. Agbor et al., "Hydrogen sulfide protects from colitis and restores intestinal microbiota biofilm and mucus production," Inflammatory Bowel Diseases, vol. 21, no. 5, pp. 1006-1017, 2015.

[53] D. R. Linden, L. Sha, A. Mazzone et al., "Production of the gaseous signal molecule hydrogen sulfide in mouse tissues," Journal of Neurochemistry, vol. 106, no. 4, pp. 1577-1585, 2008.

[54] W. Zhao, J. F. Ndisang, and R. Wang, "Modulation of endogenous production of $\mathrm{H}_{2} \mathrm{~S}$ in rat tissues," Canadian Journal of Physiology and Pharmacology, vol. 81, no. 9, pp. 848-853, 2003.

[55] S. Fiorucci, S. Orlandi, A. Mencarelli et al., "Enhanced activity of a hydrogen sulphide-releasing derivative of mesalamine (ATB-429) in a mouse model of colitis," British Journal of Pharmacology, vol. 150, no. 8, pp. 996-1002, 2007.

[56] R. Tamizhselvi, P. K. Moore, and M. Bhatia, "Inhibition of hydrogen sulfide synthesis attenuates chemokine production and protects mice against acute pancreatitis and associated lung injury," Pancreas, vol. 36, no. 4, pp. e24-e31, 2008.

[57] R. Tamizhselvi, P. K. Moore, and M. Bhatia, "Hydrogen sulfide acts as a mediator of inflammation inacute pancreatitis: in vitro studies using isolated mouse pancreatic acinar cells," Journal of Cellular and Molecular Medicine, vol. 11, no. 2, pp. 315-326, 2007.

[58] A. E. Chávez-Piña, G. R. Tapia-Álvarez, and A. Navarrete, "Inhibition of endogenous hydrogen sulfide synthesis by PAG protects against ethanol-induced gastric damage in the rat," European Journal of Pharmacology, vol. 630, no. 1-3, pp. 131-136, 2010.

[59] J. Steidle, L. Würner, and M. Diener, "Altered response to hydrogen sulphide during experimental colitis in rats," Journal of Animal Physiology and Animal Nutrition, vol. 97, no. 5, pp. 942-950, 2013.
[60] W. E. W. Roediger, J. Moore, and W. Babidge, "Colonic sulfide in pathogenesis and treatment of ulcerative colitis," Digestive Diseases and Sciences, vol. 42, no. 8, pp. 1571-1579, 1997.

[61] J. Levine, C. J. Ellis, J. K. Furne, J. Springfield, and M. D. Levitt, "Fecal hydrogen sulfide production in ulcerative colitis," The American Journal of Gastroenterology, vol. 93, no. 1, pp. 83-87, 1998.

[62] M. Althaus, K. D. Urness, W. G. Clauss, D. L. Baines, and M. Fronius, "The gasotransmitter hydrogen sulphide decreases $\mathrm{Na}^{+}$ transport across pulmonary epithelial cells," British Journal of Pharmacology, vol. 166, no. 6, pp. 1946-1963, 2012.

[63] A. Erb and M. Althaus, "Actions of hydrogen sulfide on sodium transport processes across native distal lung epithelia (Xenopus laevis)," PLoS ONE, vol. 9, no. 6, Article ID e100971, 2014.

[64] S. Ge, M. Zhao, D. Wu et al., "Hydrogen sulfide targets EGFR Cys797/Cys798 residues to induce $\mathrm{Na}^{+} / \mathrm{K}^{+}$-ATPase endocytosis and inhibition in renal tubular epithelial cells and increase sodium excretion in chronic salt-loaded rats," Antioxidants \& Redox Signaling, vol. 21, no. 15, pp. 2061-2082, 2014.

[65] Y. Kumai, C. S. Porteus, R. W. M. Kwong, and S. F. Perry, "Hydrogen sulfide inhibits $\mathrm{Na}^{+}$uptake in larval zebrafish, Danio rerio," Pflügers Archiv-European Journal of Physiology, vol. 467, no. 4, pp. 651-664, 2015.

[66] J. Zhang, S. Chen, H. Liu et al., "Hydrogen sulfide prevents hydrogen peroxide-induced activation of epithelial sodium channel through a PTEN/PI $(3,4,5) \mathrm{P}_{3}$ dependent pathway," PLoS ONE, vol. 8, no. 5, Article ID e64304, 2013.

[67] Q. Wang, B. Song, S. Jiang et al., "Hydrogen sulfide prevents advanced glycation end-products induced activation of the epithelial sodium channel," Oxidative Medicine and Cellular Longevity, vol. 2015, Article ID 976848, 10 pages, 2015.

[68] L. Jiang, J. Wang, C. Su et al., " $\alpha$-ENaC, a therapeutic target of dexamethasone on hydrogen sulfide induced acute pulmonary edema," Environmental Toxicology and Pharmacology, vol. 38, no. 2, pp. 616-624, 2014.

[69] M. Althaus, "Gasotransmitters: novel regulators of epithelial $\mathrm{Na}^{+}$transport?” Frontiers in Physiology, vol. 3, article 83, 2012.

[70] S. Kellenberger and L. Schild, "Epithelial sodium channel/degenerin family of ion channels: a variety of functions for a shared structure," Physiological Reviews, vol. 82, no. 3, pp. 735767, 2002.

[71] V. Bhalla and K. R. Hallows, "Mechanisms of ENaC regulation and clinical implications," Journal of the American Society of Nephrology, vol. 19, no. 10, pp. 1845-1854, 2008.

[72] B. C. Rossier, M. E. Baker, and R. A. Studer, "Epithelial sodium transport and its control by aldosterone: the story of our internal environment revisited," Physiological Reviews, vol. 95, no. 1, pp. 297-340, 2015.

[73] L. G. Palmer, A. Patel, and G. Frindt, "Regulation and dysregulation of epithelial $\mathrm{Na}^{+}$channels," Clinical and Experimental Nephrology, vol. 16, no. 1, pp. 35-43, 2012.

[74] R. E. Olver, C. A. Ramsden, L. B. Strang, and D. V. Walters, "The role of amiloride-blockable sodium transport in adrenalineinduced lung liquid reabsorption in the fetal lamb," Journal of Physiology, vol. 376, pp. 321-340, 1986.

[75] R. E. Olver, D. V. Walters, and S. M. Wilson, "Developmental regulation of lung liquid transport," Annual Review of Physiology, vol. 66, pp. 77-101, 2004.

[76] M. Althaus, W. G. Clauss, and M. Fronius, "Amiloride-sensitive sodium channels and pulmonary edema," Pulmonary Medicine, vol. 2011, Article ID 830320, 8 pages, 2011. 
[77] R. C. Francis, K. Vaporidi, K. D. Bloch, F. Ichinose, and W. M. Zapol, "Protective and detrimental effects of sodium sulfide and hydrogen sulfide in murine ventilator-induced lung injury," Anesthesiology, vol. 115, no. 5, pp. 1012-1021, 2011.

[78] J. Wang, H. Zhang, C. Su et al., "Dexamethasone ameliorates $\mathrm{H}_{2} \mathrm{~S}$-induced acute lung injury by alleviating matrix metalloproteinase-2 and -9 expression," PLoS ONE, vol. 9, no. 4, Article ID e94701, 2014.

[79] T. L. Guidotti, "Hydrogen sulfide: advances in understanding human toxicity," International Journal of Toxicology, vol. 29, no. 6, pp. 569-581, 2010.

[80] A. K. Mustafa, M. M. Gadalla, N. Sen et al., " $\mathrm{H}_{2} \mathrm{~S}$ signals through protein S-Sulfhydration," Science Signaling, vol. 2, no. 96, p. ra72, 2009.

[81] A. K. Mustafa, G. Sikka, S. K. Gazi et al., "Hydrogen sulfide as endothelium-derived hyperpolarizing factor sulfhydrates potassium channels," Circulation Research, vol. 109, no. 11, pp. 1259-1268, 2011.

[82] M. R. Filipovic, "Persulfidation (S-sulfhydration) and $\mathrm{H}_{2} \mathrm{~S}$," in Chemistry, Biochemistry and Pharmacology of Hydrogen Sulfide, vol. 230 of Handbook of Experimental Pharmacology, pp. 29-59, Springer, New York, NY, USA, 2015.

[83] H. Kimura, "Hydrogen sulfide and polysulfides as biological mediators," Molecules, vol. 19, no. 10, pp. 16146-16157, 2014.

[84] M. Eberhardt, M. Dux, B. Namer et al., " $\mathrm{H}_{2} \mathrm{~S}$ and NO cooperatively regulate vascular tone by activating a neuroendocrine HNO-TRPA1-CGRP signalling pathway," Nature Communications, vol. 5, article 4381, 2014.

[85] J. M. Fukuto and S. J. Carrington, "HNO signaling mechanisms," Antioxidants and Redox Signaling, vol. 14, no. 9, pp. 1649-1657, 2011.

[86] A. Hinman, H.-H. Chuang, D. M. Bautista, and D. Julius, "TRP channel activation by reversible covalent modification," Proceedings of the National Academy of Sciences of the United States of America, vol. 103, no. 51, pp. 19564-19568, 2006.

[87] L. J. Macpherson, A. E. Dubin, M. J. Evans et al., "Noxious compounds activate TRPAl ion channels through covalent modification of cysteines," Nature, vol. 445, no. 7127, pp. 541$545,2007$.

[88] M. Althaus, A. Pichl, W. G. Clauss, W. Seeger, M. Fronius, and R. E. Morty, "Nitric oxide inhibits highly selective sodium channels and the $\mathrm{Na}^{+} / \mathrm{K}^{+}$-ATPase in $\mathrm{H} 441$ cells," American Journal of Respiratory Cell and Molecular Biology, vol. 44, no. 1, pp. 53-65, 2010.

[89] Y. Yang, X. Jin, and C. Jiang, "S-glutathionylation of ion channels: insights into the regulation of channel functions, thiol modification crosstalk, and mechanosensing," Antioxidants \& Redox Signaling, vol. 20, no. 6, pp. 937-951, 2014.

[90] E. Tokhtaeva, R. J. Clifford, J. H. Kaplan, G. Sachs, and O. Vagin, "Subunit isoform selectivity in assembly of Na,K-ATPase $\alpha$ - $\beta$ heterodimers," The Journal of Biological Chemistry, vol. 287, no. 31, pp. 26115-26125, 2012.

[91] K. Geering, "FXYD proteins: new regulators of Na-K-ATPase," American Journal of Physiology - Renal Physiology, vol. 290, no. 2, pp. F241-F250, 2006.

[92] S. J. Park, T. H. Kim, S. H. Lee et al., "Expression levels of endogenous hydrogen sulfide are altered in patients with allergic rhinitis," The Laryngoscope, vol. 123, no. 3, pp. 557-563, 2013.

[93] J. W. Hwang, Y. J. Jun, S. J. Park et al., "Endogenous production of hydrogen sulfide in human sinus mucosa and its expression levels are altered in patients with chronic rhinosinusitis with and without nasal polyps," American Journal of Rhinology and Allergy, vol. 28, no. 1, pp. 12-19, 2014.

[94] A. Madurga, A. Golec, A. Pozarska et al., "The $\mathrm{H}_{2}$ S-generating enzymes cystathionine $\beta$-synthase and cystathionine $\gamma$-lyase play a role in vascular development during normal lung alveolarization," American Journal of Physiology-Lung Cellular and Molecular Physiology, vol. 309, no. 7, pp. L710-L724, 2015.

[95] J. A. Madden, S. B. Ahlf, M. W. Dantuma, K. R. Olson, and D. L. Roerig, "Precursors and inhibitors of hydrogen sulfide synthesis affect acute hypoxic pulmonary vasoconstriction in the intact lung," Journal of Applied Physiology, vol. 112, no. 3, pp. 411-418, 2012.

[96] M. R. Knowles and R. C. Boucher, "Mucus clearance as a primary innate defense mechanism for mammalian airways," The Journal of Clinical Investigation, vol. 109, no. 5, pp. 571-577, 2002.

[97] J. H. Widdicombe and J. J. Wine, "Airway gland structure and function," Physiological Reviews, vol. 95, no. 4, pp. 1241-1319, 2015.

[98] M. Althaus, "ENaC inhibitors and airway re-hydration in cystic fibrosis: state of the art," Current Molecular Pharmacology, vol. 6, no. 1, pp. 3-12, 2013.

[99] E. Kerem, T. Bistritzer, A. Hanukoglu et al., "Pulmonary epithelial sodium-channel dysfunction and excess airway liquid in pseudohypoaldosteronism," The New England Journal of Medicine, vol. 341, no. 3, pp. 156-162, 1999.

[100] X. Luan, V. A. Campanucci, M. Nair et al., "Pseudomonas aeruginosa triggers CFTR-mediated airway surface liquid secretion in swine trachea," Proceedings of the National Academy of Sciences of the United States of America, vol. 111, no. 35, pp. 12930-12935, 2014.

[101] J. H. Widdicombe, "Regulation of the depth and composition of airway surface liquid," Journal of Anatomy, vol. 201, no. 4, pp. 313-318, 2002.

[102] R. Tarran, B. R. Grubb, J. T. Gatzy, C. W. Davis, and R. C. Boucher, "The relative roles of passive surface forces and active ion transport in the modulation of airway surface liquid volume and composition," Journal of General Physiology, vol. 118, no. 2, pp. 223-236, 2001.

[103] B. Doujaiji and J. A. Al-Tawfiq, "Hydrogen sulfide exposure in an adult male," Annals of Saudi Medicine, vol. 30, no. 1, pp. 7680, 2010. 


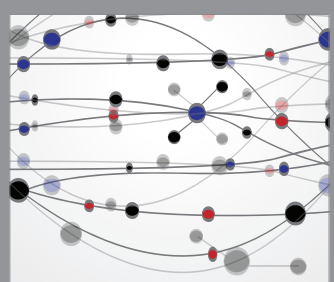

The Scientific World Journal
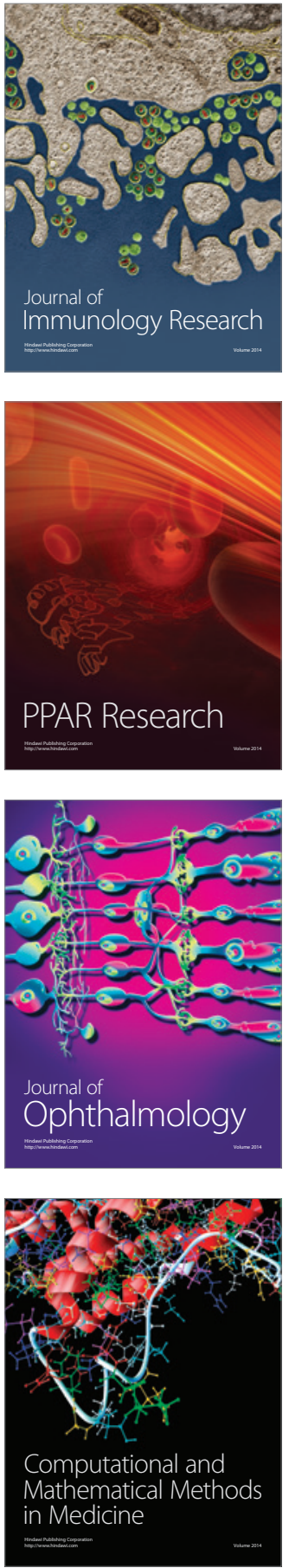

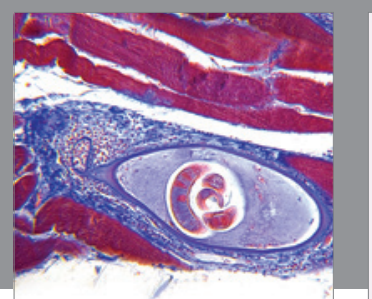

Gastroenterology Research and Practice

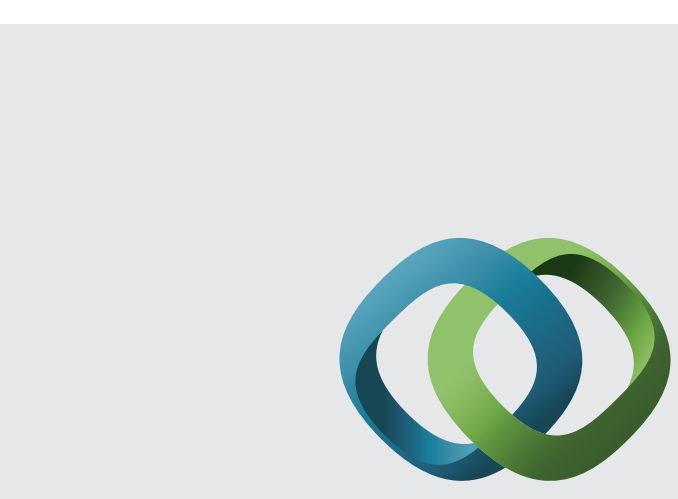

\section{Hindawi}

Submit your manuscripts at

http://www.hindawi.com
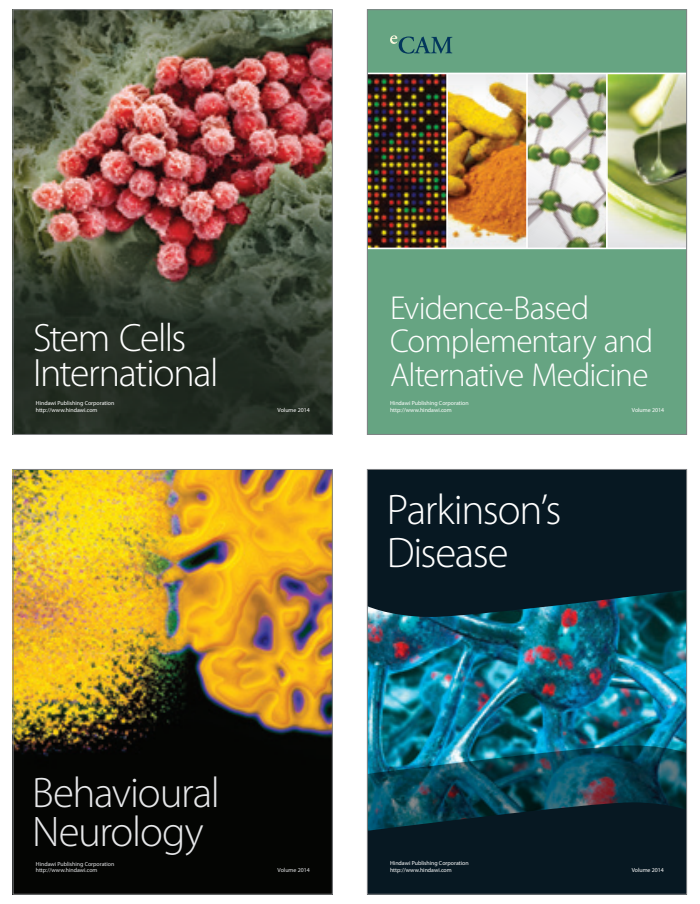
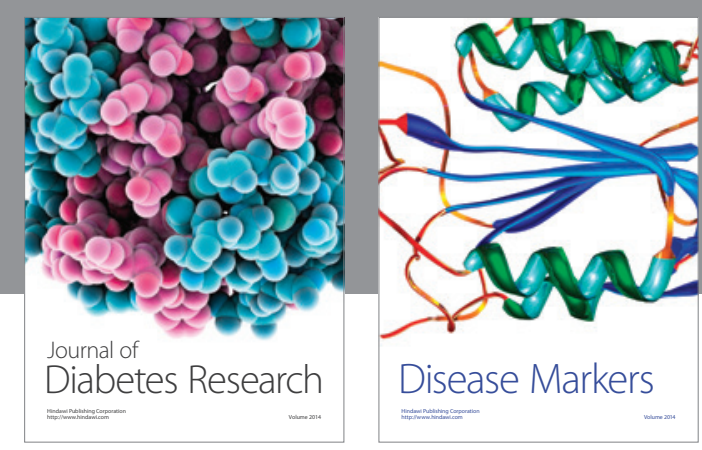

Disease Markers
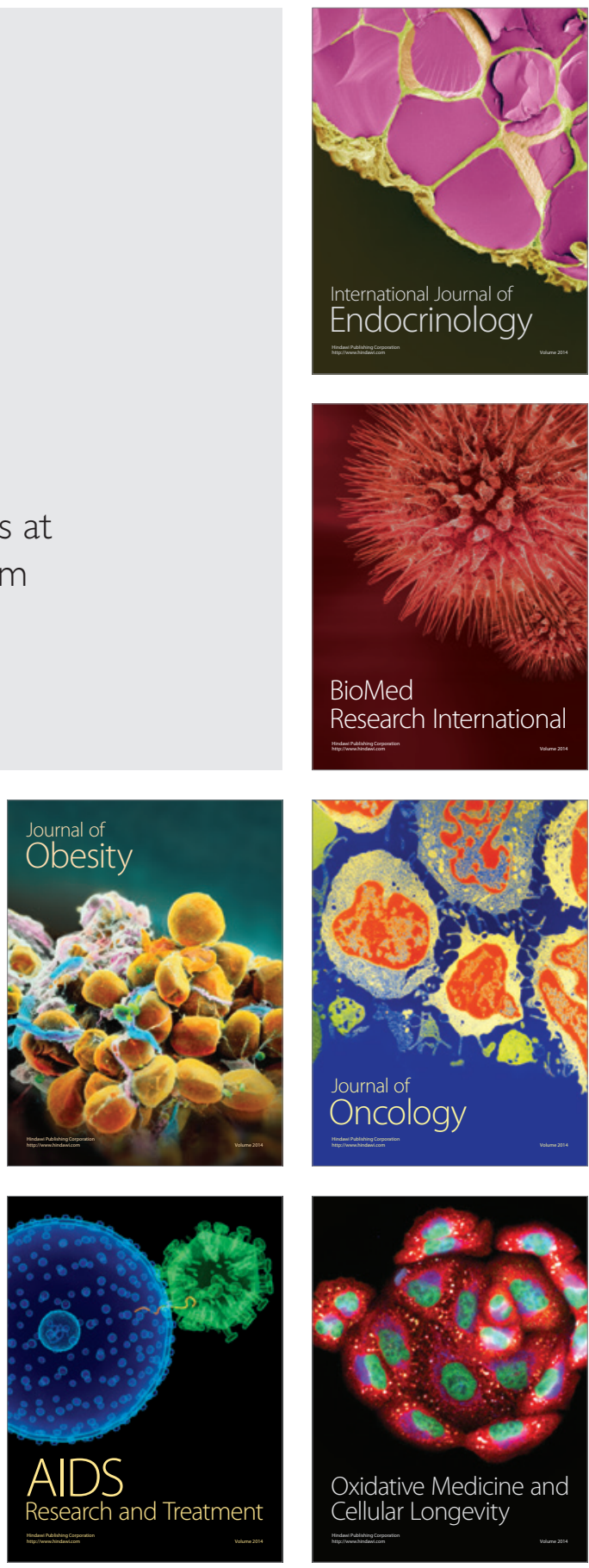